GRIPS Discussion Paper 17-13

\title{
The Quest for Quality Education: International Remittances and Rural-Urban Migration in Nepal
}

\author{
Chakra Pani Acharya \\ Roberto León-González
}

February 2018

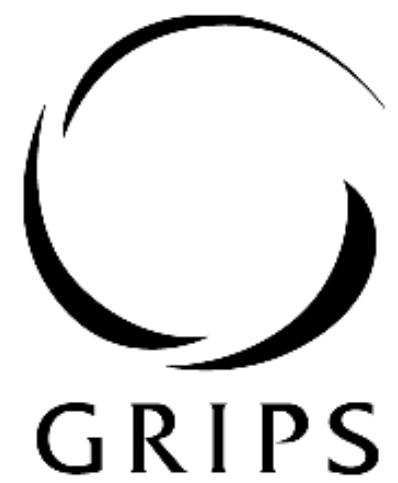

National Graduate institute FOR POLICY STUDIES

National Graduate Institute for Policy Studies

7-22-1 Roppongi, Minato-ku,

Tokyo, Japan 106-8677 


\title{
The Quest for Quality Education: International Remittances and Rural-Urban Migration in Nepal ${ }^{1}$
}

\author{
Chakra Pani Acharya \\ National Planning Commission Secretariat, Kathmandu, Nepal \\ Email: acpani2003@gmail.com/cpacharya@npc.gov.np \\ and \\ Roberto León-González \\ National Graduate Institute for Policy Studies, Tokyo, Japan
}

February 2018 (first version: March 2016)

\begin{abstract}
Despite a large growth in domestic and international migration and remittances in recent decades, there are limited works that systematically identify and establish interactions between internal and international migration. Using primary data from new urban areas of Nepal, we identify households that had migrated from rural to urban areas, explore their migration practices and educational investment behaviors, and analyze the effects of international migration and remittances on investment in education. The results show that, despite their lower income and consumption, migrant households that have members abroad have higher human capital investment measured by the level and budget share of expenditure on children's education and the time their children spend for studying at home than do urban-native and other types of migrant households. Our findings suggest that searching for better education is one important motivation for migrating to urban areas among rural households having members abroad.
\end{abstract}

Keywords: rural-urban migration; international migration; remittances; educational investment, Nepal

JELCodes: F22, F24, C24, O15

\footnotetext{
${ }^{1}$ The financial supports for the field survey was provided by Fuji Xerox Setsutaro Kobayashi Memorial Fund, Japan. The authors also acknowledge financial support from GRIPS's Policy Research Center through the project entitled "International Remittances and Investment in Education in Nepal". Ryuichi Tanaka,Yasuyuki Sawada and Ganesh Prasad Pandeya deserve special thanks for valuable suggestions and comments. We acknowledge the research assistance of Dhruba Ghimire and Nabin Acharya, enumerators and local facilitators as well as generous respondents of the survey area during field work. We declare that we do not have any competing interests that might influence this research. The contents and views expressed herein are those of the authors and do not necessarily reflect the opinions of the authors' institutions. The usual disclaimer applies.
} 


\section{Introduction}

In recent decades, the world has witnessed megatrends of migration and remittances. Approximately 700 million people are internal migrants, with most living in urban areas of developing countries (DCs), while 232 million people are international migrants, two-thirds from DCs (United Nations Population Division, 2011). In 2015, the global flow of remittances totaled $\$ 581.6$ billion, of which almost three-fourths (\$431.6 billion) went to DCs (World Bank, 2016). In fact, remittances comprised the secondlargest external resource flow (after foreign direct investment) for DCs. Despite the growing literature on the nexus among migration, remittances, and development (de Hass, 2010; Stark and Wang, 2002), few systematic attempts have been made to identify the interactions and linkages between internal and international migration that generally shape the direction and magnitude of development outcomes (for an exception, see Skeldon, 2006).

The main motivations for rural-urban migration are better employment and earnings (Harris and Todaro, 1970; Henderson, Shalizi and Venables, 2001), investment in physical and financial assets (Osili, 2004), and enjoyment of urban amenities (Fafchamps and Shilpi, 2013). Rapoport and Docquier (2006) theorize that international migration and remittances are: a mechanism for practicing altruism, that is, a desire to help members at home; insurance against risk and uncertainty for the household members left behind (Stark, 1991; Stark and Bloom, 1985); and investment in physical and human capital, without credit constraints (Carelo, Bedi and Sparrow, 2009). However, very few studies have explored the role of migration in loosening information constraints; for example, migration as a medium for the acquisition and use of knowledge and skills (Ghimre and Maharjan, 2015) and diffusion of learning and knowledge (2015; Williams and Baláž, 2008), as well as its role in information acquisition and transmission (Acharya and Leon-Gonzalez, 2014). International migration may induce information-constrained parents (e.g., uneducated mothers), who may otherwise underinvested in their children's schooling, as theorized by Becker (1993), to enroll their children in school or transfer them from a public school to a private one (Acharya and Leon-Gonzalez, 2014). However, when the performance of public schools is poor and there are few private schools in rural areas, the rise in demand for better quality education may push rural households to search for quality education by migrating to nearby urban areas or capital cities, depending upon their preferences, proximity, and capabilities. The household migration may be easier if these households 
receive non-wage income, such as international remittances. Nevertheless, to the best of our knowledge, educational investment behavior of migrant households in urban areas, who have members abroad and receive remittances, has not been explored. To fill that gap, this study explores how the desires of members of rural households receiving international remittances lead to migration to urban areas in search of better schools. We measure human-capital investment in terms of the absolute level, and budget share, of expenditure on children's education and the time the children spend studying at home. Further, we analyze whether better education for children was a motivation for their migration to urban areas.

We use primary household survey data collected from the newly developed urban areas of Nepal. This case is particularly interesting because, during the past two decades, Nepal has experienced significant progress in school enrollment and phenomenal growth in work-related foreign migration and remittance inflows as well as rural-urban family migration and urbanization. We find that rural-urban migrant families, particularly those who migrated recently and received international remittances, invest more on education and allocate a larger share of their budgets to it than urban natives with similar levels of education; they do so despite having a lower level of income and consumption. Moreover, the children of these migrant households spend more time studying at home than do children of urban-natives. While there may be other inherent reasons for migration, such as better earnings, consumption, and enjoyment of urban amenities, our findings suggest that the desire among recently arrived migrants to invest in quality schooling is one of the main motivations for their migration to urban areas, particularly if the household receives international remittances.

We also observe that the quality of children's education - a factor found to be crucial to productivity and economic growth (Barro, 1992; Hanushek and Woessamann, 2008) - has become an increasingly important concern for migrant households. The findings may have a link with the higher expected return on investment in education, which in turn causes a "brain drain" (Beine, Docquierand Rapoport, 2001) to other countries, where the return on education is much higher than in Nepal and education is often a necessary condition for such migration; for instance, in the recruitment of Gurkhas in the British Army (Shrestha, 2017). However, migrants from information-constrained households may encounter severe problems while searching for safe and better jobs; consequently they may realize the importance of education and the returns possible in the global job market. In this line, Acharya and Leon-Gonzalez (2014) showed that children 
from information-constrained households (poor, rural, or uneducated mother) improve education levels following the international migration of one member of the family, which is in contrast with the adverse effects of parental migration on children from rich, urban, and more educated households. Meanwhile, international remittances might have made the costly internal migration of rural households feasible by financing the costs of migration, settlement in urban areas, and education expenses.

The remainder of this paper is organized as follows. Section 2 provides an overview of recent political and socioeconomic changes, migration practices, and the educational system in Nepal. Section 3 describes the study's survey methodology and data. Section 4 discusses the estimation models. Section 5 presents the results, discussion, and robustness checks. Section 6 concludes the paper with policy implications.

\section{Socioeconomic Settings, Migration Practices, and Educational Systems in Nepal}

Contemporary Nepalese society is characterized by a unique socioeconomic and political transition. First, Nepal experienced political openness through the restoration of multiparty democracy in 1990 after the demise of the three-decade party-less Panchayat regime along with the adoption of a liberal economic policy that encouraged private sector engagement in education and health services and facilitated open trade and out-migration. In 2006, Nepal experienced another political change that transformed a decade-long Maoist insurgency (1996-2006) into a peace process and paved the way for restructuring the unitary state into a federal one. These changes allowed a broader participation by more than 125 castes and ethnic groups and 123 linguistic groups in the governance and development processes.

Second, Nepal experienced phenomenal growth in migration, driven by foreign employment opportunities, resulting in remittance inflows to Nepal. Annual emigration from Nepal, excluding migration to India, increased from less than 10,000 people in the early 1990 s to 418,713 people in $2015-16 .{ }^{1}$ It is estimated that at least one-third of all Nepalese households have at least one family member living abroad for employment or education (CBS, 2011), mainly in Malaysia, Qatar, Saudi Arabia, and United Arab Emirates. The recorded annual remittance inflows to Nepal increased from $\$ 50$ million in early 1990 s to $\$ 6.73$ billion in 2015 , with the ratio of remittance inflows to gross domestic product (GDP) increasing from 2 percent to 32.2 percent, making Nepal the largest remittances recipient, relative to the size of the economy (World Bank, 2016). 
Third, Nepal has made remarkable progress with regard to access to education, despite its slow economic growth and political transition. Net primary school enrollment increased from 64 percent in 1990 to 96.6 percent in 2015-16 (National Planning Commission, 2016). Focusing on knowledge of English, private sector involvement in education has increased sharply, from less than 5 percent in 1990 to 27 percent in 2010-11, with 56 percent of students enrolled in private schools in urban areas in contrast to 20 percent in rural areas (CBS, 2011).

There are considerable differences in the quality and costs of education between public and private schools. In general, the academic performance of public school students is worse than those in private schools. For instance, the pass rate in the School Leaving Certificate (SLC) exam in 2015 for public school students was 33.7 percent, compared to 89.8 percent for private school students. Among the students who passed, only 32.1 percent of public school students secured a first-division or distinction level, while the corresponding figure for private school students was 86.4 percent (MOE, 2015).

Private school fees in Nepal are paid almost entirely by the parents, unlike that in religious or other private schools in other countries. Our survey data show that average household expenditure on education per child in a private school $(\$ 221)$ is almost four times higher than that in a public school (\$58).

Fourth, Nepal has experienced remarkable urbanization in recent decades. The number of municipalities increased from 33 in 1986 to 58 in 1997 and to 217 in 2015. Accordingly, the share of the urban population increased from 9.1 percent in 1991 to 14.2 percent in 2001 and to 41.8 percent in $2015 .^{2}$ The major factor behind this growth, as in other DCs, could be rural-urban migration (Lucas, 1997). It is believed that many rural households, particularly those that receive a large amount of international remittances, have been moving to urban areas-local and newly developed urban centers, district headquarters, regional cities, and the capital city and its suburbs-depending on affordability, preferences, and access to better education, health services, and other facilities.

\section{Household Survey and Study Area}

The paper uses data collected by the first author of the Nepal Remittance Investments and Urbanization Survey (NERIUS) in late 2011. The survey defines the 41 new urban areas, which were declared municipalities by the government of Nepal (GoN) in mid-July 2011, as its study area. ${ }^{3}$ These municipalities are heterogeneously distributed 
across the country and represent newly flourishing small urban areas; they also capture the general pattern of recent rural-urban migration.

The survey adopted a three-stage stratified random sampling method. In the first stage, we randomly chose 12 urban areas, representing all three ecological belts and five development regions, based on their population shares in 2001 (see Figure 1). ${ }^{4}$ In the second stage, based on discussions with local authorities, facilitators, and community leaders, the wards of each sample municipality were categorized into three broad groups: core, characterized mainly by urban activities and the possibility of in-migration; intermediate, characterized by both urban and rural activities and might have experienced in-migration; and periphery, characterized mainly by agricultural activities and hardly experienced in-migration. One ward each from the core and intermediate groups of the 12 urban areas was randomly chosen as a primary sampling unit (PSU), producing 24 PSUs in the survey.

In the third stage, household rosters for each PSU were prepared. They included data on: household head; household size; whether the household had arrived in the study area after 2001; and the number of household members who lived abroad. Based on this information, the listed households were categorized into two groups: urban-native households (those who arrived in the municipality before 2002) and migrant households (those who arrived in the municipality after 2001). Each group of households was further divided into two categories, depending on whether at least one family member was living abroad. From these four strata, 12 households in each PSU (288 sample households) were randomly selected such that, as far as possible, at least 50 percent each were migrant households and had members living abroad. Table 1 presents the regional and ethnic distribution of the households.

\section{//Table 1 about here//}

\section{Model}

We hypothesize a model to establish a linkage between international remittances and rural-urban migration considering recent migration practice in Nepal. We assume that rural-urban migrant households generally make at least three decisions on migration and investment in human capital. First, rural households send their adult members abroad for employment and earning. Remittance income and increased knowledge about the returns to schooling may create demand for high-quality education, even though such demand might be unmet in rural areas due to the scarcity of high-quality schools. Second, the 
demand-supply mismatch in rural areas may cause rural households receiving remittances to migrate to urban areas depending upon their preferences, proximity, and ability to finance the cost of family migration. Third, migrant households make educational investment decisions, such as the types and quality of schools and expenditure amount. Thus, the household decision model is

$$
\begin{aligned}
& R_{i}^{f}=F\left(H_{i}, C_{i}, G_{i}\right) \\
& M_{i}^{d}=F\left(R_{i}^{f}, H_{i}, C_{i}, G_{i}\right) \\
& E D U_{i}=F\left(R_{i}^{f}, M_{i}^{d}, H_{i}, C_{i}, G_{i}\right)
\end{aligned}
$$

where $R^{f}, M^{d}$, and EDU are decisions on sending a member abroad who will send back remittances, migration of household from rural to urban areas, and investment in children's education, respectively. Besides household (H), community (C), and geographical $(\mathrm{G})$ attributes, the household decision on migration from rural to urban areas is determined by remittances received $\left(\mathrm{R}^{\mathrm{f}}\right)$, while educational investment is determined by the remittances received $\left(R^{f}\right)$ and decision to migrate from rural to urban areas $\left(M^{d}\right)$.

As described in Section 3, the survey covers urban areas that had witnessed migration from rural households in recent years but does not collect information on the migrants' households in the rural areas of origin. So, we cannot estimate Model (2) directly. However, we implicitly estimate Models (2) and (3) using ordinary least squares (OLS) with specification (4). Moreover, due to the limitations of the OLS methodology, we also estimate Tobit and Hurdle (Two-part) models (see Appendix A.1 for a detailed description of these models). We estimate the models separately for households receiving and not receiving international remittances to capture the impact of international migration and remittances on educational investment. We model education investment as:

$$
\operatorname{EDUINV}_{\mathrm{i}}=\beta_{0}+\beta_{1} \mathrm{M}_{\mathrm{i}}^{\mathrm{d}}+\beta_{2} \operatorname{EXP}_{\mathrm{i}}+\beta_{3} \mathrm{H}_{\mathrm{i}}+\beta_{4} \mathrm{C}_{\mathrm{i}}+\beta_{5} \mathrm{G}_{\mathrm{i}}+\varepsilon_{\mathrm{i}}
$$

where the dependent variable, EDUINV $\mathrm{i}_{\mathrm{i}}$, is household investment on education measured as the natural logarithm of household expenditure on education $\left(\text { EDUEXP }_{i}\right)^{5}$ for schoolage children (in age group 5-24 years) or its share (EDUSHARE ${ }_{i}$ ) of the household's total consumption (see appendix Table A.1 for definitions and constructions of variables). $\varepsilon_{\mathrm{i}}$ is an error term with zero mean. The model is estimated for the subsample of households that have at least one school-age child for the full sample, and separately for households that received or did not receive international remittances in the survey year. 
Among the explanatory variables, $\mathrm{M}_{\mathrm{i}}{ }^{\mathrm{d}}$, the variable of interest in this study, is a dummy variable for migrant households, equal to one if a household arrived in the PSU after 2001 and zero otherwise. EXP $\mathrm{E}_{\mathrm{i}}$ is the natural logarithm of household consumption, used as a proxy for household permanent income, as in the literature on the estimation of Engel curves. ${ }^{6} \mathrm{H}_{\mathrm{i}}$ is a vector of household characteristics, including human capital, measured as the years of schooling of the most educated member of the household who is at least 25 years old ${ }^{7}$ and household demographics measured as household size and composition. $\mathrm{C}_{\mathrm{i}}$, composed of a set of caste/ethnicity dummy variables, is used to control for differences in human and physical asset endowments and preferences with regard to schooling among castes and ethnic groups. Finally, $G_{i}$, a set of dummies for development regions, is used to control for spatial differences in access to, and preference regarding, education.

At the child level, we estimate the following human capital investment model using OLS, Tobit, and two-part (hurdle) specifications:

$$
\mathrm{CEDU}_{\mathrm{j}}=\gamma_{0}+\gamma_{1} \mathrm{M}_{\mathrm{j}}^{\mathrm{d}}+\gamma_{2} \mathrm{EXP}_{\mathrm{j}}+\gamma_{3} \mathrm{CP}_{\mathrm{j}}+\gamma_{4} \mathrm{CH}_{\mathrm{j}}+\gamma_{5} \mathrm{C}_{\mathrm{j}}+\gamma_{6} \mathrm{G}_{\mathrm{j}}+\varepsilon_{\mathrm{j}}
$$

whereCEDU $\mathrm{j}_{\mathrm{j}}$, the dependent variable, is (i) $\mathrm{CEDUEXP}_{\mathrm{j}}$, the natural logarithm of expenditure on the education of child $\mathrm{j}^{8}$ or (ii) $\mathrm{CTIME}_{\mathrm{j}}$, the number of hours that child $\mathrm{j}$ spent studying at home during the past seven days. We estimate this model in a manner similar to that used for household-level models for the full sample of children (in age group 5-24 years), and separately for subsamples of children categorized according to their household having received international remittances during the survey year. $\varepsilon_{\mathrm{j}}$ is the error term with zero mean.

The explanatory variables $\left(\mathrm{M}_{\mathrm{j}}, \mathrm{EXP}_{\mathrm{j}}, \mathrm{C}_{\mathrm{j}}\right.$, and $\left.\mathrm{G}_{\mathrm{j}}\right)$ are the same as in Model (4). $\mathrm{CP}_{\mathrm{j}}$ is a vector of child characteristics, such as dummies for age cohort and sex, birth order, and dummies for the maximum educational level of the child's parents. $\mathrm{CH}_{\mathrm{j}}$ is the natural logarithm of household size.

\section{Limitations of the study}

Household decisions on migration, remittances, and educational investment may be endogenous. First, sending a member abroad for employment and the migration of a household to urban areas might depend on observed and unobserved individual and household characteristics that also affect educational investment, which might cause an endogeneity bias. Second, remittance income and investment decisions may be 
endogenous because of the unobserved attributes, preferences, patience, and risk aversion of parents, the simultaneity of migration, remittances and children's education, and reverse causality. If we do not account for these issues properly, our estimates may be inconsistent and biased. Our survey data cover only the urban areas, where rural households have recently migrated, and do not cover the rural households. This limitation did not allow us to use the rural households in the areas of origin of migrants as a comparison group to estimate the migration decision, and find appropriate and valid instruments. Thus, we could not jointly estimate equations (1), (2), and (3) using three-stage least squares (3SLS) estimates considering the endogeneity of migration and remittances. However, we take these concerns into account when analyzing and interpreting our results.

\section{Results}

\section{Descriptive results}

Table 2 reports summary statistics for the size, composition, and education of the sample households. Among migrant households, the average time elapsed since their arrival from their hometown village is 4.95 years. On average, remittance-receiving migrant households arrived later than non-receiving migrant households. Among remittance-receiving migrant households, 79 percent had sent their members abroad prior to migration to urban areas, and 21 percent had sent them after their arrival.

// Table 2 about here //

The education levels of the most-educated household members were similar among urban-native and migrant households. However, among remittance non-receiving households, urban-natives were more educated than migrant ones, in contrast to remittance-receiving households. The proportion of young children (under 10 years) was higher among migrant households than urban-natives, while urban-natives had a higher proportion of older children (age group 11-24 years). The average number of children attending school was similar for both urban-natives and migrant households. However, migrant households were more likely to send their children to private schools than urbannatives; there is a large difference in private school enrolment between migrant and urbannative households in the subsample of remittance-receiving households.

Table 3 shows the differences in household income and consumption between migrant and urban-natives. Migrant households had lower levels of welfare measured by both average household income (panel A) and average household consumption (panel B) than urban-natives in the full sample and the sub-samples of remittance-receiving and non- 
receiving households. Foreign remittances constituted only 14 percent of the income of urban-natives but 30 percent of the income of migrant households. In the subsample of remittance-receiving households, remittance income constituted about 40 percent of income for urban-natives and 63 percent for migrant households, implying that remittance of earnings is a main source of income for migrant households. Remittance-receiving households generally had higher incomes than did non-receiving households but similar level of consumption, regardless of their being urban-native or migrant households. This suggests that remittance-receiving households saved or invested more in physical assets than non-receiving households.

\section{// Table 3 about here //}

Table 3 (panel B) shows the distribution of consumption among four categories. The food expenditure share was larger for migrant households than for urban-natives, regardless of remittances receipt. However, the average propensity to spend on non-food items and durable services was higher for urban-natives than migrant households, implying that migrants, particularly remittance-receiving ones, enjoy fewer urban amenities than urban-natives. Most importantly, remittance-receiving migrant households allocated a far larger absolute amount and budget share to education than did urban-natives, which is in line with the argument hypothesized in equation (3). These results are consistent with the pattern of school attendance (see Table 2) and the finding of De and Ratha (2012) that favorable effect of remittances on education among children in Sri Lanka, and that by Ngoma and Ismail (2013) among children in 89 developing countries.

\section{Regression estimates}

\section{Determinants of financial investment in children's education}

This subsection presents the estimates of education expenditure and its share of the budget. Table 4 summarizes the OLS, Tobit, and hurdle estimates for the natural logarithm of household expenditure on education. The coefficients of the OLS estimates (specifications [1] through [3]) and the conditional marginal effects of the Tobit estimates (specifications [4] through [6]) indicate that migrant households spend more on education than do urban-natives. However, the estimates are significant for the full sample and the subsample of remittance-receiving households but not for the subsample of non-receiving households. ${ }^{9}$ For instance, based on OLS estimates for the full sample, migrant households spend 126 percent more than do urban-natives ${ }^{10}$; for the subsample of remittance-receiving 
households, migrant households spend 209 percent more than urban-natives. The Tobit estimates are greater than the OLS estimates, suggesting that the OLS estimates are biased downward.

\section{//Table 4 about here//}

The estimates for the hurdle models (Table 4, specifications [7] through [12]) also support the OLS and Tobit estimates. The probability of having a positive expenditure on education is similar for urban-natives and migrant households in the full sample-migrant households have lower probability of having education expenditure in the subsample of remittance non-receiving households while the opposite is true in the subsample of remittance-receiving households. The education expenditure conditional on the household with positive education expenditure is higher for migrant households in all specifications and is statistically significant for all except the subsample of remittance non-receiving households. These results suggest that the higher level of investment in education among migrant households than urban-natives is due to both a greater likelihood of a positive and a higher level of spending on education among remittance-receiving households than nonreceiving ones.

Table 5 summarizes the estimates for the household budget share of education. The OLS, Tobit, and hurdle model estimation results are qualitatively similar to the estimates on expenditure amount (see Table 4) in terms of both sign and statistical significance but larger in magnitude. This suggests that remittance-receiving migrant households spend more on education and allocate a larger budget share for education than do urban-natives and non-receiving migrant households.

\section{//Table 5 about here//}

Regarding other covariates, income elasticity (consumption as a proxy) is statistically significant for all estimates of education expenditure (see Table 4, specifications [1] through [12]). However, the estimates are positive but not statistically significant for education's share of the budget (see Table 5), which implies that despite rich households spending more on education, they may not allocate a larger share of their budgets to education than poor households. In other words, poor households strive to provide for their children's education despite their lower level of asset endowment, earnings, and current consumption. The education of household member has a (always) positive and (usually) statistically significant effect on education expenditure and its share of the budget, with larger effects in the subsample of remittance-receiving households. Household size has a positive but statistically insignificant effect on education expenditure 
and its share of the budget. Education expenditure and its share of the budget increase along with the proportion of school-aged children, as expected.

Table 6 summarizes the estimates of education expenditure at the child level. The OLS and Tobit estimates for the full sample (specifications [1] and [4]) and the subsample of remittance-receiving households (specifications [3] and [6]) show that children from migrant households have a statistically significantly higher level of education expenditure than do children from urban-natives. In the full sample, children from migrant households spend 106 percent more on education than do children from non-migrant households (specification [1]). In the subsample of children from remittance-receiving households, children from migrant households spend 236 percent more on education than do children from non-migrant households (specification [3]). The coefficients of the double-hurdle models suggest that the differences in education expenditure arise from the higher likelihood of positive education expenditure among migrant households, in particular remittance-receiving ones, than among urban-natives (specifications [7] and [11]). This suggests that children from migrant households, particularly from those that receive international remittances, are more likely to be enrolled in school than children from urban-natives (similar to Table 2, panel B).

\section{//Table 6 about here//}

Table 6 also shows that children of the primary age cohort (5-10 years) have a higher level of expenditure on education than do children of the secondary (11 -16 years) and tertiary (17-24 years) age cohorts, due to higher school enrollment and a greater likelihood of enrollment in private schools (specifications [7] and [8]). This implies an increasing recognition among parents of the value of, and return on, education over time. Children of more educated parents have much higher education expenditure. The effect of parental education is stronger and greater for children of remittance-receiving households than for children of non-receiving households, revealing the higher importance attached to children's schooling by remittance-receiving ones. However, there is an acute gender gap in educational investment. On average, parents make about double the education expenditure on boys than on girls; the difference is even higher in the subsample of children of remittance-receiving households, possibly due to the better job prospects for boys in Nepal and abroad (Vogel and Korinek, 2012).

Thus, our results - regardless of the model specification-show differences in educational expenditures between rural-urban migrant households and urban-native households; remittance-receiving migrant households have larger educational expenditure 
than other types of migrant households and urban-natives, which is consistent with the higher private school enrolment among such households (see Table 2).

\section{Determinants of time allocation for children's education}

This subsection presents the results of the estimation of the time children spend studying at home. Table 7 summarizes the OLS, Tobit, and hurdle model estimates of weekly hours spent studying at home by children aged 5 to 24 . The coefficients of the OLS estimates (specifications [1] through [3]) and the conditional marginal effects of the Tobit estimates (specifications [4] through [6]) indicate that children from migrant households spend more time studying at home than do children from urban-natives. However, those estimates are statistically significant only for the full sample and the subsample of remittance-receiving households. According to the OLS estimates, in the full sample, children from migrant households spend 2.37 hours more studying at home than do children from urban-natives, while, in the subsample of remittance-receiving households, children from migrant households spend 3.48 more hours studying at home than do children from urban-native households.

//Table 7 about here//

The hurdle model estimates (Table 7, specifications [7] through [12]) also support the OLS and Tobit estimates. The probability of spending time studying at home is significantly higher for children from migrant households than for children from urbannatives, in both the full sample and the subsample of remittance-receiving households, but is insignificant in the subsample of non-receiving households. The number of hours children spend studying at home, conditional on time allocation, is greater for migrant households in all specifications but is statistically significant only for the full sample.

Table 7 also shows that children from affluent households spend more time studying at home than do children from poor households in most of the specifications. Children from large households generally spend less time studying at home than do children from small households, possibly because parents of small families place greater importance on education. Secondary school-age cohort children spend more time studying at home than do primary school-age cohort children. However, tertiary school-age cohort children spend less time studying at home than do primary school-age cohort children, possibly due to their having left school or gained employment. Boys spend more time studying at home than do girls, revealing discrimination in intra-household labor allocation. 
More educated parents allow their children to spend more time studying in both the full sample and the subsample of remittance-receiving household children.

\section{Robustness of findings}

There are three major concerns about the robustness of our results. The first concern is whether our finding on the human capital investment motivation is robust to alternative assumptions regarding the unobserved characteristics of migrant households. For example, it might be argued that households might have reasons other than their children's education (e.g., enjoyment of urban life, urban jobs) for migration to urban areas. We do not reject the hypothesis of migration for employment, earning, and consumption of urban amenities but argue that children's schooling is also an important motivation for their migration. For instance, if an urban lifestyle motivation is more important than children's education for these households, these households may have higher consumption levels for food and non-food items and may use more urban amenities and entertainment than other types of migrant and urban-native households. Moreover, if employment in urban areas is the only motivation for their migration, remittance receiving migrant households may spend more time earning a wage and less time on their children's education than other types of migrant or urban-native households. By contrast, the results show that migrant households who receive international remittances have lower wage earnings and spent significantly a smaller proportion of their total expenditure on food and non-food items than urban-natives and other types of migrant households. In addition, mothers from these households allocate more time to their children's education than urbannative or other types of migrant households (results available upon request). Moreover, we estimated the model by excluding households that have members who migrated to India to examine whether households whose members work in India incur similar expenditure on education. The results are similar in terms of sign and significance, but smaller in magnitude than our main results. This is because the proportion of households with members working in India is higher among urban-native than migrant households. We also estimate multinomial Logit models (Table A.3 in the appendix) to explain the three choices of no enrollment, enrollment in a private school, and enrolment in a public school. We find that migrant households who receive international remittances are significantly less likely to keep their children out of school and significantly more likely to enroll them

in private schools, while controlling for consumption and other characteristics. Therefore, 
it appears that searching for better education for children is one of the important reasons for migration of rural households that receive international remittances.

The second concern is whether our main findings hold true if we relax the definition of migrant households and whether the motivation of migrant households depends on the period during which they arrived. While defining a migrant household, we assumed that the households that arrived at least ten years ago are fully assimilated in urban areas, and accordingly, we defined them as urban-native households. In addition, during the decade-long Maoist conflict (1996-2006), many rural individuals and families were forced to migrate to other rural and urban areas of Nepal or abroad (Bohra-Mishra and Massey, 2011). So, we test whether our main results hold true when we relax the definition of migration household and consider reasons for any forced migration by defining households that arrived after 1990 as migrant households and creating three dummies. ${ }^{11}$ The results are consistent with the main findings (see appendix Table A.4). Pre-conflict migrant households invest less in education than do urban-natives, while both in-conflict and post-conflict migrant households invest more (although statistically insignificant) on education (panel A and B).These results are qualitatively similar to the estimation of educational expenditure at the child level (panel C). In addition, we estimate model (4) by considering households that migrated after 1990 as migrant households and dividing them into three groups - households that migrated only after sending a member abroad, households that migrated before sending a member abroad, and migrant households with no member abroad (appendix Table A.5). The results show that migrant households with member(s) abroad have a higher level of expenditure on education than other types of migrant households and urban-natives. Meanwhile, the coefficients are statistically significant and larger in magnitude for the households that sent a member abroad before migrating to urban areas than the households that sent a member only after arriving in the urban areas. The results are consistent with the argument that education is a motivation for migration to urban areas for rural households that have members abroad.

Third, we check whether expenditure on private schooling reflects the intent to invest in higher-quality education. The questionnaire used in this study asked household heads their opinions about private schools and reasons for sending their children to these schools. The survey reveals that quality was a major reason for choosing private schools. For 61 percent of the households that send at least one child to private schools, one of the following was the main reason for choosing such schools, all of which pertain to quality: teachers make more effort in teaching (32\%); classes are regular in school (19\%); and 
children put more effort in private school (10\%). The offering of English classes $(23 \%)$ was another important reason. As expected, the demonstration effect $(11 \%)$, that is, following the advice of relatives, neighbors, and friendswas not a very important factor in the decision. These views are well-supported by the differences between the SLC examination results of public schools and private schools (see Section 2). In addition,

private schooling was more common for primary school-age cohort than for the secondary school-age cohort, suggesting a growing trend for private schooling.

The findings above are consistent with the brain drain hypothesis mentioned earlier, and is amplified among migrant households via information acquisition and remittancefinanced rural-urban migration. Parents are increasingly investing in higher-quality education, perhaps anticipating higher returns to education in the global market, despite uncertainty in the domestic environment. In addition, the robustness checks are consistent with our argument and validate the hypothesis that investment in higher-quality education of children is an important motivation for migration to urban areas among rural households receiving international remittances.

\section{Conclusion}

This paper analyzed the effects of international migration and remittances on the human-capital investment behavior of rural-urban migrant households. We considered the level and budget share of expenditure on children's education and the time their children spend studying at home as indicators of human capital investment. We tested whether search for better education was an important motivation for migration of international remittance-receiving rural households to urban areas. The results showed that despite having lower levels of income and consumption, the rural-urban migrant households that receive international remittances spend, on average, three times more on education and allocate a larger share of their budgets to education than urban-natives and other types of migrant households. In addition, children from these migrant households spend more time studying at home than children from other types of households. These findings suggest that an important motivation for rural-urban migration is the search for human-capital investment. This is because of the assumption that the international migration exposes households to observe higher returns to quality education in international labor markets, and international remittances help finance the costs of both rural-urban migration and children's education. Our findings imply that income level is not the primary factor for 
investments in children's education; rather, exposure to global employment opportunities and increased importance of quality education may be the main factors.

Understanding the human-capital investment behavior of rural-urban migrant households may help policy makers to review the existing migration policy of Nepal for getting maximum benefits from the international labor markets. Strategies that focus on providing information about the costs of, and returns to, education in local and global labor markets may be crucial for achieving optimal investment in children's schooling. In addition, providing incentives, such as education vouchers, establishment of vocational schools and colleges, and upgrading facilities of public schools, particularly in rural areas, may supplement in achieving more equitable and optimal, educational outcomes.

1 Data are taken from the Department of Foreign Employment of Nepal (2016). Under a reciprocal agreement between Nepal and India, the Nepalese can enter India through an open border and work there without a visa. Therefore, estimating the annual flow of the Nepalese people to India is difficult. It is estimated that more than 2 million Nepalese migrants live in India.

2 Figures are based on Nepal's population censuses for 1991, 2001, and 2011.

3 The GoN's declaration was not implemented immediately. Rather, in July 2014, the GoN declared 72 new municipalities, including 41 urban areas surveyed in this study. An additional 61 municipalities were declared in December 2014 and 26 municipalities in September 2015.

4 During the survey, CBS had released the preliminary results of the 2011 population censusonly up to the district level; therefore, we could not obtain data at the local administrative (village development committee or municipality) level. Instead, we used data from the 2001 population census to prepare the primary sampling frame.

5 We use the natural logarithm of one plus EDUEXP as a dependent variable to avoid missing values while taking the $\log$.

6 Following Deaton and Zaidi (2002), we calculated household income and consumption (see Table A.1 in the appendix). We allowed for the nonlinearity of consumption by including its squared and cubed terms, but those did not generate statistically significant coefficients. Therefore, we proceeded with a linear Engel curve.

7 We assume that school-aged children (5-24 years) are less likely to engage in income-earning activities. Accordingly, their education level should not directly affect the household's current income but may affect the household's future income. Therefore, in calculating the years of schooling of the most educated adult member of the household, we excluded school-age children. The results using the years of schooling of the most educated member of the household aged 17 or above (not reported here) are robust to our main results shown in Table 4, but the $\mathrm{R}^{2}$ is drastically smaller.

8 We used the natural logarithm of one plus CEDU as a dependent variable to avoid the problem of missing values while taking log.

9 Alternatively, we also estimated the model in the subsample of households with members abroad and not. The results, reported in the appendix (Table A.2), are consistent with our main findings. Similarly, we also defined households having a returned or current international migrant member(s) as household with international migrants and estimated the model in the subsample of households with migrant members abroad and not. Again, the results were found to be consistent with our main findings.

10 According to Kennedy (1981), it would not be correct to interpret the coefficient of the migration dummy (0.873) as migrant households spending 87.3 percent more expenditure on education than non-migrant households, other things being equal. Instead, following the formula proposed by Kennedy, it would be more accurate to state that the migrant households have 126 percent [i.e. $100\left(\exp \left(0.873-0.5\left(0.34^{2}\right)\right)\right.$ $1)=125.96 \%$ ] higher expenditure on education than non-migrant households, other things being equal.

11 Three dummies - prior-conflict migrant households (those that arrived in the urban area between 1991 and 1995), in-conflict migrant households (those that arrived in the urban area between 1996 and 2006), and postconflict migrant households (those that arrived in the urban area after 2006) - are used for migrant households 
with a dummy for urban-native households (including those arrived in the urban area before 1991) as the base category. 


\section{References}

Acharya, C.P. \& Leon-Gonzalez, R. (2014). How do migration and remittances affect human capital investment? The effects of relaxing information and liquidity constraints. Journal of Development Studies, 50, 444-460. doi:10.1080/00220388.2013.866224

Adams, R.H. \&Cuecuecha, A. (2010). Remittances, household expenditure and investment in Guatemala. World Development, 38, 1626-1641. doi:10.1016/j.worlddev.2010.03.003

Barro, R. (1992). Human capital and economic growth. In Policies for long run economic growth, Federal Reserve Bank of Kansas City. Retrieved from http://www.kc.frb.org.

Becker, G.S. (1993). A theoretical and empirical analysis with special reference to education (3rd ed.). Chicago and London: The University of Chicago Press.

Beine, M., Docquier, F. \&Rapoport, H. (2001). Brain drain and economic growth: Theory and evidence. Journal of Development Economics, 64, 275-289.doi:10.1016/S0304-3878(00)00133-4

Bohra-Mishra, P.\& Massey, D.S. (2011). Individual decisions to migrate during civil conflict. Demography, 48, 401424.doi:10.1007/s13524-011-0016-5

Calero, C., Bedi, A.\& Sparrow, R. (2009). Remittances, liquidity constraints and human capital investments in Ecuador. World Development, 37, 1143-1154. doi:10.1016/j.worlddev.2008.10.006

Cameron, A.C. \& Trivedi, P.K. (2005). Microeconometrics: Methods and applications. Cambridge: Cambridge University Press.

Central Bureau of Statistics (2011). Nepal living standards survey 2009/10 (Vols. 1-2). Kathmandu: The Author.

de Haas, H. (2010). Migration and development: A theoretical perspective. International Migration Review, 44, $227-$ 264. doi:10.1111/j.1747-7379.2009.00804.x

De, P.K. \&Ratha, D. (2012). Impact of remittances on household income, asset and human capital: Evidence from Sri Lanka. Migration and Development, 1(1): 163-179. doi:10.1080/21632324.2012.719348

Deaton, A. (1997). The analysis of household surveys: A microeconometric approach to development policy. Baltimore, MD: Johns Hopkins University Press.

Deaton, A. \& Zaidi, S. (2002). Guidelines for constructing consumption aggregates for welfare analysis (Living Standards Measurement Study Working Paper 135). Washington, DC: World Bank.

Department of Foreign Employment of Nepal (2016). Annual progress report 2015-16. Retrieved from http://www.dofe.gov.np.

Fafchamps, M. \&Shilpi, F. (2013). Determinants of the choice of migration destination. Oxford Bulletin of Economics and Statistics, 75: 388-409. doi:10.1111/j.1468-0084.2012.00706.x

Ghimre, A. \&Maharjan, K. (2015). Student returnees and their reflection on contribution to Nepal: Use of knowledge and skills. Migration and Development, 4(1): 90-107.doi:10.1080/21632324.2014.935148

Hanushek, E.A.\&Woessamann, L. (2008). The role of cognitive skills in economic development. Journal of Economic Literature, 46: 607-668. doi:10.1257/jel.46.3.607

Harris, J. \&Todaro, M. (1970). Migration, unemployment and development: A two-sector analysis. American Economic Review, 60: 126-142. Retrieved from http://www.jstor.org/stable/1807860

Henderson, V., Shalizi, Z. \&Venables, A.J. (2001). Geography and development. Journal of Economic Geography,1: 81-105.doi:10.1093/jeg/1.1.81 
Kennedy, P., (1981). Estimation with correctly interpreted dummy variables in semilogarithmic equations. American Economic Review, 71: 801.

Lucas R. (1997). Internal migration in developing countries. In M.R. Rosenzweig\& O. Stark (Eds.), Handbook of Population and Family Economics (Vol. 1B) (pp. 721-798). Amsterdam: Elsevier-North-Holland.

Ministry of Education (2015). Nepal education figures 2015: At a glance. Retrieved from http://www.moe.gov.np.

National Planning Commission (2016). Nepal and the Millennium Development Goals final status report 20002015.Kathmandu: The Author.

Ngoma, A.L. \& Ismail, N.W. (2013). Do migrant remittances promote human capital formation? Evidence from 89 developing countries. Migration and Development, 2(1): 106-116. doi: 10.1080/21632324.2013.786883

Osili, U.O. (2004). Migrants and housing investments: Theory and evidence from Nigeria. Economic Development and Cultural Change, 52: 821-849. doi:10.1086/420903.

Rapoport, H. \&Docquier, F. (2006). The economics of migrants' remittances, in: S. Kolm and J.Mercier-Ythier (eds) Handbook on the Economics of Giving, Altruism and Reciprocity (pp. 1138-1195).New York: Elsevier-North Holland.

Shrestha, S. A. (2017). No man left behind: Effects of emigration prospects on educational and labor outcomes of non-migrants. Economic Journal, 127: 495-521. doi:10.1111/ecoj.12306.

Skeldon, R. (2006). Interlinkages between internal and international migration and development in the Asian Region. Population, Space and Place, 12: 15-30. doi:10.1002/psp.385

Stark, O. (1991). The migration of labor. Cambridge, Massachusetts: Blackwell.

Stark, O.\& Bloom, D.E. (1985). The new economics of labor migration. American Economic Review, 75: $173-78$. http://www.jstor.org/stable/1805591

Stark, O. \& Wang, Y. (2002). Inducing human capital formation: Migration as a substitute for subsidies. Journal of Public Economics, 86: 29-46.doi:10.1016/S0047-2727(01)00104-9

United Nations Population Division (2011). Trends in international migrant stock: Migrants by age and sex (United Nations database, POP/DB/MIG/Stock/Rev.2011). New York: UN Department of Economic and Social Affairs.

Vogel, A. \&Korinek, K. (2012). Passing by the girls? Remittance allocation for educational expenditures and social inequality in Nepal's households 2003-2004.International Migration Review, 46: 1-60. doi:10.1111/j.17477379.2012.00881.x

Williams, A.M. \&Baláž, V. (2008). International Migration and Knowledge. Oxon: Rutledge.

Wooldridge, J.M. (2002). Econometric Analysis of Cross Section and Panel Data. Cambridge, Massachusetts: MIT Press.

World Bank (2016). Migration and Development Brief 26. Retrieved from http://pubdocs.worldbank.org. 


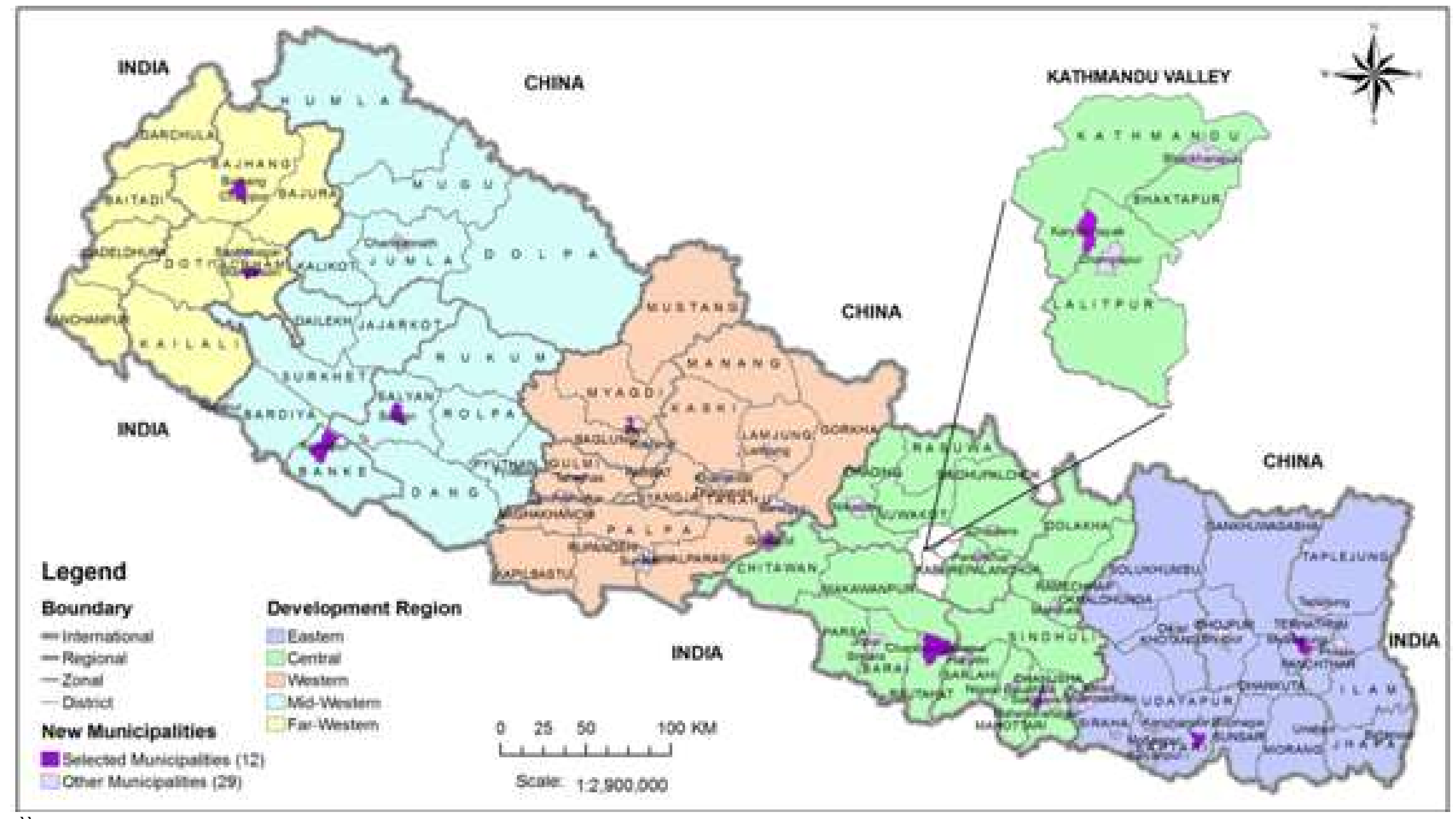

X“'xxxxxxxxxxxxx 
Table 1. Sampling Distribution of Households

\begin{tabular}{|c|c|c|c|c|}
\hline & \multicolumn{2}{|c|}{ Urban-native households } & \multicolumn{2}{|c|}{ Migrant households } \\
\hline & $\begin{array}{l}\text { Having members } \\
\text { abroad }\end{array}$ & $\begin{array}{l}\text { No member } \\
\text { abroad }\end{array}$ & $\begin{array}{l}\text { Having } \\
\text { members abroad }\end{array}$ & $\begin{array}{l}\text { No member } \\
\text { abroad }\end{array}$ \\
\hline \multicolumn{5}{|l|}{ A. Full study area } \\
\hline No of households in sampling frame & 1,728 & 4,520 & 640 & 1,808 \\
\hline No of sample households & 64 & 113 & 53 & 58 \\
\hline $\begin{array}{l}\text { Percent of sample households in } \\
\text { sampling frame }\end{array}$ & 19.87 & 51.98 & 7.36 & 20.79 \\
\hline \multicolumn{5}{|l|}{$\begin{array}{l}\text { B. Ecological Belt } \\
\text { (Distribution by household types) }\end{array}$} \\
\hline Mountains & 13.36 & 81.23 & 1.08 & 4.33 \\
\hline Hills & 21.05 & 47.65 & 7.25 & 24.05 \\
\hline Tarai & 19.60 & 52.25 & 8.31 & 19.85 \\
\hline \multicolumn{5}{|l|}{$\begin{array}{l}\text { C. Development Region } \\
\text { (Distribution by household types) }\end{array}$} \\
\hline Eastern & 18.95 & 50.83 & 6.77 & 23.46 \\
\hline Central & 16.86 & 55.97 & 7.12 & 20.05 \\
\hline Western & 25.28 & 39.06 & 11.66 & 24.00 \\
\hline Mid-Western & 13.34 & 56.61 & 5.99 & 24.06 \\
\hline Far-Western & 26.45 & 67.15 & 0.62 & 5.79 \\
\hline
\end{tabular}


Table 2. Household Composition and Education by Migration and International Remittances

\begin{tabular}{|c|c|c|c|c|c|c|}
\hline \multirow{2}{*}{ Variable } & \multicolumn{2}{|c|}{ All households } & \multicolumn{2}{|c|}{$\begin{array}{l}\text { Households not receiving } \\
\text { international remittances }\end{array}$} & \multicolumn{2}{|c|}{$\begin{array}{c}\text { Households receiving } \\
\text { international remittances }\end{array}$} \\
\hline & $\begin{array}{l}\text { Urban- } \\
\text { native }\end{array}$ & Migrant & $\begin{array}{l}\text { Urban- } \\
\text { native }\end{array}$ & Migrant & $\begin{array}{l}\text { Urban- } \\
\text { native }\end{array}$ & Migrant \\
\hline Years Since Migration (YSM) & n.a. & 4.95 & n.a. & 5.28 & n.a. & 4.58 \\
\hline \multicolumn{7}{|l|}{ A. Household size and composition } \\
\hline Household size & 4.95 & 4.08 & 5.23 & 3.97 & 4.45 & 4.21 \\
\hline Household size ${ }^{\S}$ & 6.15 & 5.27 & 6.11 & 4.55 & 6.23 & 6.06 \\
\hline \multicolumn{7}{|l|}{ Proportion of children } \\
\hline aged $0-4$ & 0.08 & 0.09 & 0.08 & 0.09 & 0.08 & 0.08 \\
\hline aged $5-10$ & 0.11 & 0.17 & 0.11 & 0.16 & 0.10 & 0.17 \\
\hline aged $11-16$ & 0.13 & 0.11 & 0.15 & 0.10 & 0.11 & 0.12 \\
\hline aged $17-24$ & 0.19 & 0.18 & 0.19 & 0.18 & 0.19 & 0.17 \\
\hline Proportion of adult men aged $25-64$ & 0.22 & 0.25 & 0.19 & 0.25 & 0.27 & 0.24 \\
\hline Proportion of adult women aged 25-64 & 0.22 & 0.19 & 0.23 & 0.19 & 0.21 & 0.19 \\
\hline Proportion of elderly $(64+)$ & 0.05 & 0.02 & 0.06 & 0.03 & 0.05 & 0.02 \\
\hline \multicolumn{7}{|l|}{ B. Education } \\
\hline $\begin{array}{l}\text { Years of schooling of the most educated } \\
\text { adult member (aged } 25 \text { and above) }\end{array}$ & 8.84 & 8.73 & 8.87 & 8.16 & 8.80 & 9.36 \\
\hline \multicolumn{7}{|l|}{ No of children (aged 5-24) in } \\
\hline School & 1.70 & 1.70 & 1.88 & 1.52 & 1.39 & 1.91 \\
\hline Public/Community school & 0.88 & 0.65 & 1.04 & 0.71 & 0.59 & 0.58 \\
\hline Private school & 0.82 & 1.05 & 0.84 & 0.81 & 0.80 & 1.32 \\
\hline No of households $(\mathrm{N})$ & 177 & 111 & 113 & 58 & 64 & 53 \\
\hline
\end{tabular}

Note.See Table 1 notes. ${ }^{\S}$ Including absent members also. 
Table 3. Household Income and Consumption by Migration and Remittances

\begin{tabular}{|c|c|c|c|c|c|c|}
\hline \multirow{2}{*}{ Variable } & \multicolumn{2}{|c|}{ All households } & \multicolumn{2}{|c|}{$\begin{array}{l}\text { Households not receiving } \\
\text { international remittances }\end{array}$} & \multicolumn{2}{|c|}{$\begin{array}{c}\text { Households receiving } \\
\text { international remittances }\end{array}$} \\
\hline & $\begin{array}{l}\text { Urban } \\
\text { native }\end{array}$ & Migrant & $\begin{array}{l}\text { Urban } \\
\text { native }\end{array}$ & Migrant & $\begin{array}{l}\text { Urban } \\
\text { native }\end{array}$ & Migrant \\
\hline \multicolumn{7}{|l|}{ A: Income (NPR thousand) } \\
\hline Household income & 380.46 & 301.69 & 340.18 & 251.42 & 451.57 & 356.69 \\
\hline Per capita income & 92.65 & 82.26 & 74.45 & 76.95 & 124.78 & 88.08 \\
\hline $\begin{array}{l}\text { Foreign remittance } \\
\text { income }\end{array}$ & 53.23 & 90.90 & 0.00 & 0.00 & 174.71 & 225.11 \\
\hline \multicolumn{7}{|l|}{$\begin{array}{l}\text { C: Consumption } \\
\text { (NPR housand }) \quad t\end{array}$} \\
\hline Household consumption & 260.22 & 212.61 & 266.36 & 203.42 & 249.38 & 222.67 \\
\hline Per capita consumption & 62.16 & 55.69 & 60.41 & 55.46 & 65.23 & 55.95 \\
\hline \multicolumn{7}{|l|}{$\begin{array}{l}\text { D: Consumption by } \\
\text { categories (NPR } \\
\text { thousand) }\end{array}$} \\
\hline Food & $\begin{array}{c}99.65 \\
(41.33)\end{array}$ & $\begin{array}{c}89.67 \\
(44.78)\end{array}$ & $\begin{array}{l}101.62 \\
(40.56)\end{array}$ & $\begin{array}{c}84.70 \\
(43.65)\end{array}$ & $\begin{array}{c}96.18 \\
(42.70)\end{array}$ & $\begin{array}{c}95.11 \\
(46.02)\end{array}$ \\
\hline Non-food & $\begin{array}{c}128.66 \\
(47.78)\end{array}$ & $\begin{array}{l}90.91 \\
(41.08)\end{array}$ & $\begin{array}{c}130.84 \\
(47.90)\end{array}$ & $\begin{array}{l}89.56 \\
(42.88)\end{array}$ & $\begin{array}{c}124.79 \\
(47.57)\end{array}$ & $\begin{array}{l}92.38 \\
(39.12)\end{array}$ \\
\hline Durable services & $\begin{array}{l}10.76 \\
(3.30)\end{array}$ & $\begin{array}{c}8.30 \\
(3.54)\end{array}$ & $\begin{array}{l}12.00 \\
(3.72)\end{array}$ & $\begin{array}{c}9.75 \\
(4.34)\end{array}$ & $\begin{array}{c}8.58 \\
(2.56)\end{array}$ & $\begin{array}{c}6.72 \\
(2.67)\end{array}$ \\
\hline Education & $\begin{array}{l}21.02 \\
(7.59)\end{array}$ & $\begin{array}{c}23.64 \\
(10.59)\end{array}$ & $\begin{array}{l}21.77 \\
(7.83)\end{array}$ & $\begin{array}{l}19.32 \\
(9.13)\end{array}$ & $\begin{array}{l}19.71 \\
(7.17)\end{array}$ & $\begin{array}{c}28.37 \\
(12.19)\end{array}$ \\
\hline No of households (N) & 177 & 111 & 113 & 58 & 64 & 53 \\
\hline
\end{tabular}

Note. See Table 1. See Appendix (Table A.1) for construction of variables. 
Table 4. OLS, Tobit and Two-Part Estimates of Natural Logarithm of Household Expenditure on Education (Household Level)

\begin{tabular}{|c|c|c|c|c|c|c|c|c|c|c|c|c|}
\hline \multirow{5}{*}{ Variables } & \multicolumn{3}{|c|}{ A. OLS Model } & \multicolumn{3}{|c|}{ B. Tobit Model } & \multicolumn{6}{|c|}{ C. Two-Part Model } \\
\hline & All & $\begin{array}{c}\text { Remittance } \\
\text { non-recipient }\end{array}$ & $\begin{array}{c}\text { Remittance } \\
\text { recipient }\end{array}$ & All & $\begin{array}{c}\text { Remittance } \\
\text { non-recipient }\end{array}$ & $\begin{array}{c}\text { Remittance } \\
\text { recipient }\end{array}$ & \multicolumn{2}{|c|}{ All } & \multicolumn{2}{|c|}{ Remittance non-recipient } & \multicolumn{2}{|c|}{ Remittance recipient } \\
\hline & \multirow{2}{*}{ Coeff. } & \multirow{2}{*}{ Coeff. } & \multirow{2}{*}{ Coeff. } & \multirow{2}{*}{$\begin{array}{l}\text { Condi. Mar. } \\
\text { effect }\end{array}$} & \multirow{2}{*}{$\begin{array}{l}\text { Condi. Mar. } \\
\text { effect }\end{array}$} & \multirow{2}{*}{$\begin{array}{l}\text { Condi. } \\
\text { Mar. effect }\end{array}$} & Probit & OLS & Probit & OLS & Probit & OLS \\
\hline & & & & & & & Mar. effect & Coeff. & Mar. effect & Coeff. & Mar. effect & Coeff. \\
\hline & $(1)$ & $(2)$ & (3) & (4) & $(5)$ & $(6)$ & $(7)$ & $(8)$ & $(9)$ & $(10)$ & $(11)$ & $(12)$ \\
\hline Migrant household (M) & $\begin{array}{c}0.873 * * \\
(0.340)\end{array}$ & $\begin{array}{c}0.431 \\
(0.482)\end{array}$ & $\begin{array}{l}1.326^{* *} \\
(0.634)\end{array}$ & $\begin{array}{c}0.958^{* *} \\
(0.396)\end{array}$ & $\begin{array}{c}0.471 \\
(0.486)\end{array}$ & $\begin{array}{l}1.465^{* *} \\
(0.631)\end{array}$ & $\begin{array}{c}0.013 \\
(0.028)\end{array}$ & $\begin{array}{c}0.284 * * * \\
(0.096)\end{array}$ & $\begin{array}{l}-0.050^{*} \\
(0.027)\end{array}$ & $\begin{array}{c}0.225 \\
(0.155)\end{array}$ & $\begin{array}{c}0.275^{* *} \\
(0.119)\end{array}$ & $\begin{array}{l}0.211^{*} \\
(0.120)\end{array}$ \\
\hline Log of household expenditure & $\begin{array}{c}2.047^{* * *} \\
(0.465)\end{array}$ & $\begin{array}{c}1.900^{* * *} \\
(0.721)\end{array}$ & $\begin{array}{c}2.261^{* * *} \\
(0.702)\end{array}$ & $\begin{array}{c}2.173^{* * *} \\
(0.463)\end{array}$ & $\begin{array}{c}1.956^{* * *} \\
(0.594)\end{array}$ & $\begin{array}{c}2.453 * * * \\
(0.726)\end{array}$ & $\begin{array}{c}0.119^{* * *} \\
(0.038)\end{array}$ & $\begin{array}{c}0.998^{* * *} \\
(0.122)\end{array}$ & $\begin{array}{c}0.180^{* * *} \\
(0.057)\end{array}$ & $\begin{array}{c}0.965^{* * *} \\
(0.196)\end{array}$ & $\begin{array}{l}0.254^{* *} \\
(0.100)\end{array}$ & $\begin{array}{c}1.004^{* * *} \\
(0.164)\end{array}$ \\
\hline \multirow[t]{2}{*}{$\begin{array}{l}\text { Years of schooling of the most } \\
\text { educated adult aged } 25\end{array}$} & $0.117 * * *$ & 0.042 & $0.198 * *$ & $0.130^{* * *}$ & 0.045 & $0.225 * *$ & 0.004 & $0.034 * * *$ & -0.000 & $0.026^{*}$ & $0.016^{* *}$ & $0.056^{* * *}$ \\
\hline & $(0.043)$ & $(0.056)$ & $(0.085)$ & $(0.046)$ & $(0.051)$ & $(0.085)$ & $(0.003)$ & $(0.010)$ & $(0.003)$ & $(0.014)$ & $(0.007)$ & $(0.018)$ \\
\hline Log of household size & $\begin{array}{c}0.493 \\
(0.483)\end{array}$ & $\begin{array}{c}0.206 \\
(0.744)\end{array}$ & $\begin{array}{c}0.169 \\
(0.790)\end{array}$ & $\begin{array}{c}0.572 \\
(0.501)\end{array}$ & $\begin{array}{l}0.268 \\
(0.619)\end{array}$ & $\begin{array}{c}0.230 \\
(0.798)\end{array}$ & $\begin{array}{l}-0.041 \\
(0.042)\end{array}$ & $\begin{array}{c}0.031 \\
(0.133)\end{array}$ & $\begin{array}{l}-0.104 * \\
(0.054)\end{array}$ & $\begin{array}{l}-0.065 \\
(0.209)\end{array}$ & $\begin{array}{l}-0.093 \\
(0.077)\end{array}$ & $\begin{array}{l}-0.014 \\
(0.168)\end{array}$ \\
\hline Proportion of children aged $0-4$ & $\begin{array}{l}-4.483 \\
(2.838)\end{array}$ & $\begin{array}{l}-5.775 \\
(3.955)\end{array}$ & $\begin{array}{l}-0.606 \\
(4.133)\end{array}$ & $\begin{array}{l}-5.235^{* *} \\
(2.648)\end{array}$ & $\begin{array}{c}-6.550^{* *} \\
(3.066)\end{array}$ & $\begin{array}{l}-1.172 \\
(4.513)\end{array}$ & $\begin{array}{l}-0.205 \\
(0.164)\end{array}$ & $\begin{array}{l}-0.163 \\
(0.736)\end{array}$ & $\begin{array}{c}0.235 \\
(0.191)\end{array}$ & $\begin{array}{l}-0.676 \\
(1.102)\end{array}$ & & $\begin{array}{c}1.130 \\
(0.989)\end{array}$ \\
\hline Proportion of children aged 5-10 & $\begin{array}{l}8.188^{* * *} \\
(2.665)\end{array}$ & $\begin{array}{l}4.768 \\
(3.973)\end{array}$ & $\begin{array}{c}13.162^{* * *} \\
(3.253)\end{array}$ & $\begin{array}{l}8.859^{* * *} \\
(2.596)\end{array}$ & $\begin{array}{l}4.957 \\
(3.105)\end{array}$ & $\begin{array}{c}14.570^{* * *} \\
(3.974)\end{array}$ & $\begin{array}{c}1.423^{* * *} \\
(0.304)\end{array}$ & $\begin{array}{l}1.598^{* *} \\
(0.694)\end{array}$ & $\begin{array}{c}1.748^{* * *} \\
(0.502)\end{array}$ & $\begin{array}{c}0.986 \\
(1.048)\end{array}$ & & $\begin{array}{c}3.015^{* * *} \\
(0.891)\end{array}$ \\
\hline \multirow{2}{*}{$\begin{array}{l}\text { Proportion of children aged } 11- \\
16\end{array}$} & 3.867 & 2.350 & $6.801^{* *}$ & $4.100^{*}$ & 2.375 & $7.374 * *$ & $0.279 *$ & $1.238^{*}$ & $0.453 * *$ & 0.683 & $-0.369 * *$ & $2.561 * * *$ \\
\hline & $(2.616)$ & (3.945) & (3.104) & (2.408) & $(2.916)$ & $(3.702)$ & $(0.165)$ & $(0.650)$ & $(0.185)$ & $(1.002)$ & $(0.162)$ & $(0.826)$ \\
\hline \multirow{2}{*}{$\begin{array}{l}\text { Proportion of children aged 17- } \\
24\end{array}$} & 3.070 & 1.630 & 3.685 & 3.276 & 1.570 & 4.153 & 0.174 & $1.187 *$ & $0.549 * *$ & 0.654 & $-0.925 * * *$ & $2.231^{* * *}$ \\
\hline & $(2.405)$ & (3.689) & (3.059) & $(2.452)$ & $(2.966)$ & $(3.672)$ & $(0.178)$ & $(0.649)$ & $(0.215)$ & $(1.003)$ & $(0.209)$ & $(0.799)$ \\
\hline \multirow[t]{2}{*}{$\begin{array}{l}\text { Proportion of working age men } \\
(25-64)\end{array}$} & 0.470 & 2.199 & 1.300 & 0.611 & 2.508 & 1.530 & 0.042 & -0.437 & $0.467 * *$ & -1.075 & $-1.086^{* * *}$ & 0.238 \\
\hline & $(2.874)$ & (3.956) & $(4.235)$ & $(2.692)$ & $(3.295)$ & $(4.043)$ & $(0.190)$ & $(0.724)$ & $(0.210)$ & (1.102) & $(0.320)$ & $(0.917)$ \\
\hline \multirow[t]{2}{*}{$\begin{array}{l}\text { Proportion of working age } \\
\text { women ( } 25-64)\end{array}$} & 3.826 & 5.457 & -0.287 & 4.225 & $5.845^{*}$ & -0.306 & 0.162 & 0.401 & $1.169 * * *$ & -0.139 & -0.256 & $1.686^{*}$ \\
\hline & $(2.440)$ & $(3.392)$ & $(3.862)$ & $(2.849)$ & (3.359) & $(4.569)$ & $(0.188)$ & $(0.736)$ & $(0.399)$ & (1.106) & $(0.345)$ & $(0.975)$ \\
\hline \multicolumn{13}{|l|}{ Caste/Ethnicity } \\
\hline Brahmin-Hills & $\begin{array}{c}0.447 \\
(0.567)\end{array}$ & $\begin{array}{l}-0.412 \\
(0.630)\end{array}$ & $\begin{array}{c}0.639 \\
(0.839)\end{array}$ & $\begin{array}{c}0.528 \\
(0.636)\end{array}$ & $\begin{array}{l}-0.426 \\
(0.765)\end{array}$ & $\begin{array}{c}0.755 \\
(0.998)\end{array}$ & $\begin{array}{c}0.022 \\
(0.033)\end{array}$ & $\begin{array}{l}-0.066 \\
(0.116)\end{array}$ & $\begin{array}{l}-0.001 \\
(0.032)\end{array}$ & $\begin{array}{c}0.003 \\
(0.175)\end{array}$ & & $\begin{array}{l}-0.022 \\
(0.157)\end{array}$ \\
\hline Brahmin-Tarai & $\begin{array}{c}0.133 \\
(0.622)\end{array}$ & $\begin{array}{l}-0.303 \\
(0.722)\end{array}$ & $\begin{array}{c}1.861 \\
(1.351)\end{array}$ & $\begin{array}{c}0.147 \\
(0.923)\end{array}$ & $\begin{array}{l}-0.353 \\
(0.978)\end{array}$ & $\begin{array}{c}2.081 \\
(1.932)\end{array}$ & & & & & & \\
\hline Chhetri & $\begin{array}{c}0.272 \\
(0.489)\end{array}$ & $\begin{array}{l}-0.033 \\
(0.473)\end{array}$ & $\begin{array}{l}-0.312 \\
(0.909)\end{array}$ & $\begin{array}{c}0.314 \\
(0.596)\end{array}$ & $\begin{array}{l}-0.025 \\
(0.745)\end{array}$ & $\begin{array}{l}-0.315 \\
(0.901)\end{array}$ & $\begin{array}{c}0.017 \\
(0.031)\end{array}$ & $\begin{array}{c}0.117 \\
(0.105)\end{array}$ & $\begin{array}{l}-0.015 \\
(0.032)\end{array}$ & $\begin{array}{c}0.202 \\
(0.162)\end{array}$ & $\begin{array}{l}-0.042 \\
(0.051)\end{array}$ & $\begin{array}{c}0.155 \\
(0.140)\end{array}$ \\
\hline Newar & $\begin{array}{c}0.018 \\
(1.007)\end{array}$ & $\begin{array}{c}0.362 \\
(0.509)\end{array}$ & $\begin{array}{l}-0.433 \\
(2.461)\end{array}$ & $\begin{array}{c}0.062 \\
(0.977)\end{array}$ & $\begin{array}{c}0.381 \\
(1.095)\end{array}$ & $\begin{array}{l}-0.370 \\
(1.750)\end{array}$ & & & & & & \\
\hline
\end{tabular}




\begin{tabular}{|c|c|c|c|c|c|c|c|c|c|c|c|c|}
\hline \multirow{5}{*}{ Variables } & \multicolumn{3}{|c|}{ A. OLS Model } & \multicolumn{3}{|c|}{ B. Tobit Model } & \multicolumn{6}{|c|}{ C. Two-Part Model } \\
\hline & All & $\begin{array}{c}\text { Remittance } \\
\text { non-recipient }\end{array}$ & $\begin{array}{l}\text { Remittance } \\
\text { recipient }\end{array}$ & All & $\begin{array}{c}\text { Remittance } \\
\text { non-recipient }\end{array}$ & $\begin{array}{c}\text { Remittance } \\
\text { recipient }\end{array}$ & \multicolumn{2}{|c|}{ All } & \multicolumn{2}{|c|}{ Remittance non-recipient } & \multicolumn{2}{|c|}{ Remittance recipient } \\
\hline & & & & Condi. Mar. & Condi. Mar. & Condi. & Probit & OLS & Probit & OLS & Probit & OLS \\
\hline & Coeff. & Coeff. & Coeff. & effect & effect & Mar. effect & Mar. effect & Coeff. & Mar. effect & Coeff. & Mar. effect & Coeff. \\
\hline & $(1)$ & (2) & (3) & (4) & $(5)$ & (6) & (7) & $(8)$ & (9) & $(10)$ & $(11)$ & $(12)$ \\
\hline Ethnic Groups -Hills & $\begin{array}{l}-0.979 \\
(0.629)\end{array}$ & $\begin{array}{c}-2.007 * * \\
(0.927)\end{array}$ & $\begin{array}{l}-1.053 \\
(0.978)\end{array}$ & $\begin{array}{l}-1.082 \\
(0.691)\end{array}$ & $\begin{array}{c}-2.259^{* *} \\
(0.921)\end{array}$ & $\begin{array}{l}-1.103 \\
(0.956)\end{array}$ & & & & & $\begin{array}{c}-0.276^{* *} \\
(0.113)\end{array}$ & \\
\hline Dalit & $\begin{array}{l}1.525^{* *} \\
(0.726)\end{array}$ & $\begin{array}{c}0.995 \\
(0.720)\end{array}$ & $\begin{array}{c}0.772 \\
(1.276)\end{array}$ & $\begin{array}{l}1.757^{* *} \\
(0.767)\end{array}$ & $\begin{array}{c}1.101 \\
(0.917)\end{array}$ & $\begin{array}{c}1.076 \\
(1.263)\end{array}$ & & & & & & \\
\hline \multicolumn{13}{|l|}{ Development Regions } \\
\hline Eastern & $\begin{array}{c}0.502 \\
(0.575)\end{array}$ & $\begin{array}{c}0.846 \\
(0.599)\end{array}$ & $\begin{array}{l}-2.257^{*} \\
(1.295)\end{array}$ & $\begin{array}{c}0.501 \\
(0.656)\end{array}$ & $\begin{array}{c}0.878 \\
(0.702)\end{array}$ & $\begin{array}{l}-2.491 * \\
(1.386)\end{array}$ & $\begin{array}{c}0.074 \\
(0.046)\end{array}$ & $\begin{array}{l}0.226^{*} \\
(0.130)\end{array}$ & & $\begin{array}{c}0.428 * * \\
(0.184)\end{array}$ & & $\begin{array}{l}-0.187 \\
(0.198)\end{array}$ \\
\hline Central & $\begin{array}{c}0.176 \\
(0.623)\end{array}$ & $\begin{array}{l}-0.191 \\
(0.772)\end{array}$ & $\begin{array}{l}-1.076 \\
(0.993)\end{array}$ & $\begin{array}{c}0.152 \\
(0.615)\end{array}$ & $\begin{array}{l}-0.241 \\
(0.663)\end{array}$ & $\begin{array}{l}-1.210 \\
(1.250)\end{array}$ & $\begin{array}{c}0.016 \\
(0.034)\end{array}$ & $\begin{array}{c}0.281^{* *} \\
(0.121)\end{array}$ & $\begin{array}{l}-0.019 \\
(0.030)\end{array}$ & $\begin{array}{c}0.434^{* *} \\
(0.180)\end{array}$ & & $\begin{array}{l}-0.005 \\
(0.155)\end{array}$ \\
\hline Western & $\begin{array}{l}-0.661 \\
(0.587)\end{array}$ & $\begin{array}{c}0.049 \\
(0.720)\end{array}$ & $\begin{array}{c}-2.818^{* * *} \\
(1.054)\end{array}$ & $\begin{array}{l}-0.785 \\
(0.601)\end{array}$ & $\begin{array}{c}0.006 \\
(0.675)\end{array}$ & $\begin{array}{c}-3.120^{* *} \\
(1.201)\end{array}$ & $\begin{array}{c}-0.074 * * \\
(0.037)\end{array}$ & $\begin{array}{c}0.150 \\
(0.129)\end{array}$ & $\begin{array}{c}-0.131 * * * \\
(0.046)\end{array}$ & $\begin{array}{c}0.286 \\
(0.195)\end{array}$ & $\begin{array}{c}-0.179 * * * \\
(0.062)\end{array}$ & $\begin{array}{l}-0.247 \\
(0.171)\end{array}$ \\
\hline Mid-western & $\begin{array}{l}-0.425 \\
(0.692)\end{array}$ & $\begin{array}{c}0.289 \\
(0.660)\end{array}$ & $\begin{array}{c}-2.699 * * \\
(1.321)\end{array}$ & $\begin{array}{l}-0.488 \\
(0.601)\end{array}$ & $\begin{array}{c}0.289 \\
(0.674)\end{array}$ & $\begin{array}{c}-2.979 * * \\
(1.186)\end{array}$ & & & & & $\begin{array}{c}-0.159 * * * \\
(0.043)\end{array}$ & \\
\hline Constant & $\begin{array}{c}-21.328^{* * *} \\
(5.940)\end{array}$ & $\begin{array}{c}-17.567^{*} \\
(9.326)\end{array}$ & $\begin{array}{c}-23.104 * * * \\
(7.724)\end{array}$ & $\begin{array}{c}-23.476^{* * *} \\
(5.812)\end{array}$ & $\begin{array}{c}-18.549 * * \\
(7.555)\end{array}$ & $\begin{array}{c}-26.218^{* * *} \\
(8.760)\end{array}$ & & $\begin{array}{c}-3.606^{* *} \\
(1.547)\end{array}$ & & $\begin{array}{l}-2.622 \\
(2.492)\end{array}$ & & $\begin{array}{c}-4.503 * * \\
(1.996)\end{array}$ \\
\hline Observations & 247 & 145 & 102 & 247 & 145 & 102 & 247 & 225 & 145 & 135 & 102 & 90 \\
\hline Left censored observations & & & & 22 & 10 & 12 & & & & & & \\
\hline $\mathrm{R}^{2} /$ Pseudo- $\mathrm{R}^{2}$ & 0.42 & 0.42 & 0.59 & 0.11 & 0.12 & 0.17 & 0.56 & 0.44 & 0.65 & 0.35 & 0.63 & 0.66 \\
\hline Log likelihood & & & & -551.2 & -308.5 & -220.8 & -32.79 & & -12.62 & & -13.56 & \\
\hline
\end{tabular}


Table 5. OLS, Tobit and Two-Part Estimates of Budget Share (\%) of Expenditure on Education (Household Level)

\begin{tabular}{|c|c|c|c|c|c|c|c|c|c|c|c|c|}
\hline \multirow{5}{*}{ Variables } & \multicolumn{3}{|c|}{ A. OLS Model } & \multicolumn{3}{|c|}{ B. Tobit Model } & \multicolumn{6}{|c|}{ C. Two-Part Model } \\
\hline & \multirow{3}{*}{$\frac{\text { All }}{\text { Coeff. }}$} & \multirow{3}{*}{$\begin{array}{c}\begin{array}{c}\text { Remittance } \\
\text { non-recipient }\end{array} \\
\text { Coeff. }\end{array}$} & \multirow{3}{*}{$\begin{array}{c}\begin{array}{c}\text { Remittance } \\
\text { recipient }\end{array} \\
\text { Coeff. }\end{array}$} & \multirow{3}{*}{$\begin{array}{c}\text { All } \\
\begin{array}{c}\text { Condi. Mar. } \\
\text { effect }\end{array}\end{array}$} & \multirow{3}{*}{$\begin{array}{c}\begin{array}{c}\text { Remittance } \\
\text { non-recipient }\end{array} \\
\begin{array}{c}\text { Condi. Mar. } \\
\text { effect }\end{array}\end{array}$} & \multirow{3}{*}{$\begin{array}{c}\begin{array}{c}\text { Remittance } \\
\text { recipient }\end{array} \\
\begin{array}{c}\text { Condi. } \\
\text { Mar. effect }\end{array}\end{array}$} & \multicolumn{2}{|c|}{ All } & \multicolumn{2}{|c|}{ Remittance non-recipient } & \multicolumn{2}{|c|}{ Remittance recipient } \\
\hline & & & & & & & Probit & OLS & Probit & OLS & Probit & OLS \\
\hline & & & & & & & Mar. effect & Coeff. & Mar. effect & Coeff. & Mar. effect & Coeff. \\
\hline & $(1)$ & $(2)$ & (3) & (4) & $(5)$ & $(6)$ & $(7)$ & $(8)$ & (9) & $(10)$ & $(11)$ & $(12)$ \\
\hline \multirow[t]{2}{*}{ Migrant household (M) } & $2.270^{* *}$ & 1.383 & 2.533 & $2.159^{* * *}$ & 1.322 & $2.661 * *$ & 0.013 & $2.538 * * *$ & $-0.050 *$ & 1.678 & $0.275^{* *}$ & 2.086 \\
\hline & $(0.991)$ & $(1.448)$ & $(1.645)$ & $(0.805)$ & $(1.104)$ & $(1.245)$ & $(0.028)$ & $(0.897)$ & $(0.027)$ & $(1.344)$ & $(0.119)$ & $(1.313)$ \\
\hline \multirow[t]{2}{*}{ Log of household expenditure } & 0.373 & 0.344 & 0.748 & 0.682 & 0.488 & 0.987 & $0.119 * * *$ & -0.505 & $0.180^{* * * *}$ & -0.709 & $0.254^{* *}$ & -0.919 \\
\hline & $(1.293)$ & $(2.028)$ & $(1.947)$ & $(0.942)$ & $(1.342)$ & $(1.439)$ & $(0.038)$ & $(1.147)$ & $(0.057)$ & $(1.700)$ & $(0.100)$ & $(1.796)$ \\
\hline \multirow{2}{*}{$\begin{array}{l}\text { Years of schooling of the most } \\
\text { educated adult aged } 25\end{array}$} & $0.329^{* * *}$ & 0.188 & $0.481^{* *}$ & $0.303^{* * *}$ & 0.154 & $0.533^{* * *}$ & 0.004 & $0.313^{* * *}$ & -0.000 & $0.230^{*}$ & $0.016^{* *}$ & $0.585^{* * *}$ \\
\hline & $(0.110)$ & $(0.151)$ & $(0.221)$ & $(0.093)$ & $(0.116)$ & $(0.172)$ & $(0.003)$ & $(0.098)$ & $(0.003)$ & $(0.118)$ & $(0.007)$ & $(0.201)$ \\
\hline \multirow[t]{2}{*}{ Log of household size } & 0.832 & -0.530 & -0.356 & 0.919 & -0.169 & -0.065 & -0.041 & 0.215 & $-0.104^{*}$ & -0.942 & -0.093 & 0.142 \\
\hline & $(1.211)$ & $(1.632)$ & $(2.228)$ & $(1.017)$ & $(1.400)$ & $(1.574)$ & $(0.042)$ & $(1.249)$ & $(0.054)$ & $(1.809)$ & $(0.077)$ & $(1.847)$ \\
\hline \multirow[t]{2}{*}{ Proportion of children aged $0-4$} & -4.574 & -8.171 & 9.806 & -5.789 & -8.946 & 6.741 & -0.205 & -0.578 & 0.235 & -2.277 & & 9.440 \\
\hline & $(5.724)$ & $(8.335)$ & (7.463) & $(5.430)$ & $(7.002)$ & $(9.055)$ & $(0.164)$ & $(6.904)$ & $(0.191)$ & $(9.538)$ & & $(10.845)$ \\
\hline \multirow[t]{2}{*}{ Proportion of children aged 5-10 } & $22.773^{* * *}$ & $15.378^{*}$ & $38.193^{* * *}$ & $20.510^{* * *}$ & $12.857^{*}$ & $37.947 * * *$ & $1.423 * * *$ & $18.226^{* * *}$ & $1.748 * * *$ & 13.040 & & $32.193^{* * *}$ \\
\hline & $(6.057)$ & $(8.619)$ & $(8.000)$ & $(5.294)$ & $(7.029)$ & $(7.927)$ & $(0.304)$ & $(6.514)$ & $(0.502)$ & $(9.070)$ & & $(9.768)$ \\
\hline \multirow{2}{*}{$\begin{array}{l}\text { Proportion of children aged 11- } \\
16\end{array}$} & $15.864 * * *$ & 10.785 & $28.205^{* * *}$ & $13.565^{* * *}$ & 8.638 & $26.986^{* * *}$ & $0.279^{*}$ & $14.707 * *$ & $0.453^{* *}$ & 10.467 & $-0.369^{* *}$ & $27.312 * * *$ \\
\hline & $(5.471)$ & $(8.002)$ & $(7.332)$ & $(4.911)$ & $(6.607)$ & $(7.383)$ & $(0.165)$ & $(6.101)$ & $(0.185)$ & $(8.676)$ & $(0.162)$ & $(9.057)$ \\
\hline \multirow{2}{*}{$\begin{array}{l}\text { Proportion of children aged } 17- \\
24\end{array}$} & $14.045^{* *}$ & 10.160 & $18.740 * * *$ & $12.014 * *$ & 7.866 & $18.194 * *$ & 0.174 & $13.529^{* *}$ & $0.549^{* *}$ & 10.346 & $-0.925^{* * *}$ & $21.941^{* *}$ \\
\hline & $(5.552)$ & $(8.346)$ & $(6.469)$ & $(4.987)$ & $(6.713)$ & $(7.293)$ & $(0.178)$ & $(6.091)$ & $(0.215)$ & $(8.686)$ & $(0.209)$ & $(8.762)$ \\
\hline \multirow{2}{*}{$\begin{array}{l}\text { Proportion of working age men } \\
(25-64)\end{array}$} & -2.609 & -4.263 & 2.514 & -1.944 & -2.449 & 2.306 & 0.042 & -4.528 & $0.467^{* *}$ & -9.105 & $-1.086^{* * *}$ & 0.965 \\
\hline & $(6.294)$ & $(8.605)$ & $(8.874)$ & $(5.482)$ & (7.444) & $(8.063)$ & $(0.190)$ & $(6.796)$ & $(0.210)$ & $(9.542)$ & $(0.320)$ & $(10.059)$ \\
\hline \multirow[t]{2}{*}{$\begin{array}{l}\text { Proportion of working age } \\
\text { women (25-64) }\end{array}$} & 8.885 & 6.861 & $13.712^{*}$ & 8.402 & 7.032 & 12.045 & 0.162 & 6.167 & $1.169^{* * *}$ & 0.974 & -0.256 & $19.130^{*}$ \\
\hline & $(5.648)$ & $(8.319)$ & (7.939) & $(5.767)$ & $(7.563)$ & $(9.026)$ & $(0.188)$ & $(6.911)$ & $(0.399)$ & $(9.577)$ & $(0.345)$ & $(10.689)$ \\
\hline \multirow[t]{2}{*}{ Constant } & -11.412 & -4.456 & -16.427 & -15.939 & -7.348 & -21.416 & & 3.990 & & 11.398 & & 0.769 \\
\hline & $(15.606)$ & $(25.583)$ & (19.834) & $(11.853)$ & $(17.093)$ & $(17.363)$ & & $(14.524)$ & & $(21.572)$ & & $(21.886)$ \\
\hline Observations & 247 & 145 & 102 & 247 & 145 & 102 & 247 & 225 & 145 & 135 & 102 & 90 \\
\hline Left censored observations & & & & 22 & 10 & 12 & & & & & & \\
\hline $\mathrm{R}^{2} /$ Pseudo- $\mathrm{R}^{2}$ & 0.29 & 0.22 & 0.52 & 0.06 & 0.04 & 0.12 & 0.56 & 0.23 & 0.65 & 0.24 & 0.63 & 0.37 \\
\hline Log likelihood & & & & -750.0 & -445.7 & -288.4 & -32.79 & & -12.62 & & -13.56 & \\
\hline
\end{tabular}

Note. The sample includes only the households which have children aged between 5 and 24 . Similar to Table 4 , caste/ethnicity dummies and development regions dummies are included in the models but estimates are not included for brevity and are available upon request. Standard errors in parentheses are robust to heteroskedasticity. $* * *$, and $* * *$ indicate the $10 \%, 5 \%$ and $1 \%$ level of statistical significance respectively. 
Table 6. OLS, Tobit and Two-Part Estimates of Natural Logarithm of Expenditure on Education (Children aged 5-24)

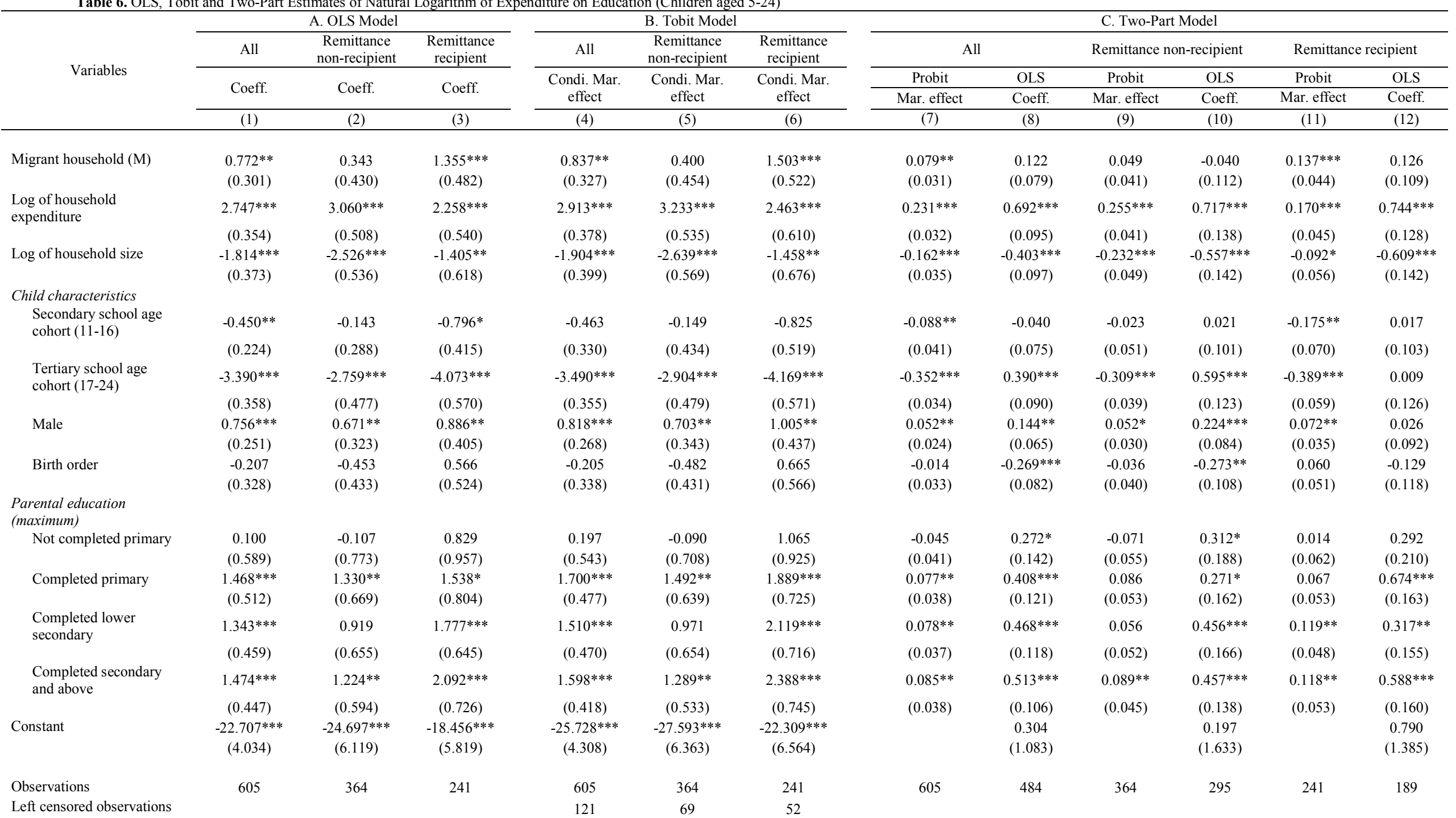




\begin{tabular}{|c|c|c|c|c|c|c|c|c|c|c|c|c|}
\hline \multirow{5}{*}{ Variables } & \multicolumn{3}{|c|}{ A. OLS Model } & \multicolumn{3}{|c|}{ B. Tobit Model } & \multicolumn{6}{|c|}{ C. Two-Part Model } \\
\hline & All & $\begin{array}{c}\text { Remittance } \\
\text { non-recipient }\end{array}$ & $\begin{array}{c}\text { Remittance } \\
\text { recipient }\end{array}$ & All & $\begin{array}{c}\text { Remittance } \\
\text { non-recipient }\end{array}$ & $\begin{array}{c}\text { Remittance } \\
\text { recipient }\end{array}$ & \multicolumn{2}{|c|}{ All } & \multicolumn{2}{|c|}{ Remittance non-recipient } & \multicolumn{2}{|c|}{ Remittance recipient } \\
\hline & & & & Condi. Mar. & Condi. Mar. & Condi. Mar. & Probit & OLS & Probit & OLS & Probit & OLS \\
\hline & Coeff. & Coeff. & Coeff. & effect & effect & effect & Mar. effect & Coeff. & Mar. effect & Coeff. & Mar. effect & Coeff. \\
\hline & $(1)$ & $(2)$ & (3) & (4) & $(5)$ & $(6)$ & $(7)$ & $(8)$ & (9) & $(10)$ & (11) & $(12)$ \\
\hline $\mathrm{R}^{2} /$ Pseudo- $\mathrm{R}^{2}$ & 0.38 & 0.38 & 0.50 & 0.09 & 0.08 & 0.13 & 0.42 & 0.40 & 0.41 & 0.43 & 0.53 & 0.55 \\
\hline Log likelihood & & & & -1436 & -872.7 & -550.7 & -174.9 & & -104.9 & & -59.71 & \\
\hline
\end{tabular}

Log likelihood

Note. Dependent variable is natural logarithm of one plus expenditure on education for children to avoid missing values. Primary school age cohort (5-10) is the base group for age cohort. Non-literate or no formal schooling is the base category for parental education. Similar to Table 4, caste/ethnicity dummies and development regions dummies are included in the models but estimates are not included for brevity and are available upon request. Standard errors in parentheses are robust to heteroskedasticity and clustered at residuals within each household. *,**, and $* * *$ indicate the $10 \%, 5 \%$ and $1 \%$ level of statistical significance respectively. 


\begin{tabular}{|c|c|c|c|c|c|c|c|c|c|c|c|c|}
\hline \multirow{4}{*}{ Variables } & \multirow{4}{*}{$\begin{array}{c}\text { All } \\
\text { Coeff. } \\
(1)\end{array}$} & \multirow{4}{*}{$\begin{array}{c}\begin{array}{c}\text { Remittance } \\
\text { non-recipient }\end{array} \\
\text { Coeff. } \\
(2) \\
\end{array}$} & \multirow{4}{*}{$\begin{array}{c}\begin{array}{c}\text { Remittance } \\
\text { recipient }\end{array} \\
\text { Coeff. } \\
(3)\end{array}$} & \multirow{4}{*}{\begin{tabular}{|c|} 
All \\
$\begin{array}{c}\text { Condi. Mar. } \\
\text { effect }\end{array}$ \\
Cond. \\
(4)
\end{tabular}} & \multirow{4}{*}{$\begin{array}{c}\begin{array}{c}\text { Remittance } \\
\text { non-recipient }\end{array} \\
\begin{array}{c}\text { Condi. Mar. } \\
\text { effect }\end{array} \\
\text { Cond. } \\
(5) \\
\end{array}$} & \multirow{4}{*}{$\begin{array}{c}\begin{array}{c}\text { Remittance } \\
\text { recipient }\end{array} \\
\begin{array}{c}\text { Condi. Mar. } \\
\text { effect }\end{array} \\
\text { Cond. } \\
\text { (6) } \\
\end{array}$} & \multicolumn{2}{|c|}{ All } & \multicolumn{2}{|c|}{ Remittance non-recipient } & \multicolumn{2}{|c|}{ Remittance recipient } \\
\hline & & & & & & & Probit & OLS & Probit & OLS & Probit & OLS \\
\hline & & & & & & & Mar. effect & Coeff. & Mar. effect & Coeff. & Mar. effect & Coeff. \\
\hline & & & & & & & (7) & (8) & (9) & $(10)$ & (11) & (12) \\
\hline Migrant household (M) & $\begin{array}{c}2.372 * * * \\
(0.753)\end{array}$ & $\begin{array}{c}1.057 \\
(1.044)\end{array}$ & $\begin{array}{c}3.478 * * * \\
(1.165)\end{array}$ & $\begin{array}{c}1.926 * * * \\
(0.628)\end{array}$ & $\begin{array}{c}0.848 \\
(0.869)\end{array}$ & $\begin{array}{c}3.008 * * * \\
(0.994)\end{array}$ & $\begin{array}{l}0.057 * \\
(0.031)\end{array}$ & $\begin{array}{l}1.705 * * \\
(0.727)\end{array}$ & $\begin{array}{c}0.024 \\
(0.040)\end{array}$ & $\begin{array}{c}0.835 \\
(0.995)\end{array}$ & $\begin{array}{c}0.129^{* * *} \\
(0.044)\end{array}$ & $\begin{array}{c}1.410 \\
(1.157)\end{array}$ \\
\hline Log of household expenditure & $\begin{array}{c}4.776^{* * *} \\
(0.900)\end{array}$ & $\begin{array}{c}6.448 * * * \\
(1.131)\end{array}$ & $\begin{array}{c}1.548 \\
(1.538)\end{array}$ & $\begin{array}{c}4.297 * * * \\
(0.723)\end{array}$ & $\begin{array}{c}5.765 * * * \\
(1.022)\end{array}$ & $\begin{array}{c}1.792 \\
(1.158)\end{array}$ & $\begin{array}{c}0.194 * * * \\
(0.033)\end{array}$ & $\begin{array}{c}2.298^{* * * *} \\
(0.850)\end{array}$ & $\begin{array}{c}0.202 * * * \\
(0.047)\end{array}$ & $\begin{array}{c}4.582 * * * \\
(1.186)\end{array}$ & $\begin{array}{c}0.143 * * * \\
(0.044)\end{array}$ & $\begin{array}{l}-1.770 \\
(1.346)\end{array}$ \\
\hline Log of household size & $\begin{array}{c}-2.879^{* * *} \\
(1.085)\end{array}$ & $\begin{array}{c}-5.690^{* * *} \\
(1.296)\end{array}$ & $\begin{array}{c}0.478 \\
(1.922)\end{array}$ & $\begin{array}{c}-2.607 * * * \\
(0.766)\end{array}$ & $\begin{array}{c}-4.988^{* * *} \\
(1.091)\end{array}$ & $\begin{array}{c}0.074 \\
(1.285)\end{array}$ & $\begin{array}{c}-0.141 * * * \\
(0.035)\end{array}$ & $\begin{array}{l}-0.849 \\
(0.893)\end{array}$ & $\begin{array}{c}-0.185^{* * *} \\
(0.048)\end{array}$ & $\begin{array}{c}-3.669 * * * \\
(1.251)\end{array}$ & $\begin{array}{l}-0.082 \\
(0.054)\end{array}$ & $\begin{array}{l}2.951^{*} \\
(1.504)\end{array}$ \\
\hline \multicolumn{13}{|l|}{ Child characteristics } \\
\hline Secondary school age cohort & $\begin{array}{c}2.138^{* * *} \\
(0.702)\end{array}$ & $\begin{array}{c}2.344 * * * \\
(0.886)\end{array}$ & $\begin{array}{l}2.126^{*} \\
(1.182)\end{array}$ & $\begin{array}{l}1.473 * * \\
(0.631)\end{array}$ & $\begin{array}{l}1.811^{* *} \\
(0.829)\end{array}$ & $\begin{array}{c}1.338 \\
(0.983)\end{array}$ & $\begin{array}{l}-0.048 \\
(0.041)\end{array}$ & $\begin{array}{c}2.557^{* * * *} \\
(0.692)\end{array}$ & $\begin{array}{c}0.029 \\
(0.055)\end{array}$ & $\begin{array}{c}2.214^{* *} \\
(0.899)\end{array}$ & $\begin{array}{c}-0.146^{* *} \\
(0.067)\end{array}$ & $\begin{array}{c}3.917 * * * \\
(1.087)\end{array}$ \\
\hline Tertiary school age cohort & $\begin{array}{c}-3.981 * * * \\
(0.841)\end{array}$ & $\begin{array}{c}-4.027 * * * \\
(1.067)\end{array}$ & $\begin{array}{c}-3.611^{* *} \\
(1.413)\end{array}$ & $\begin{array}{c}-4.222 * * * \\
(0.685)\end{array}$ & $\begin{array}{c}-4.197^{* * *} \\
(0.924)\end{array}$ & $\begin{array}{c}-4.107^{* * *} \\
(1.088)\end{array}$ & $\begin{array}{c}-0.327 * * * \\
(0.032)\end{array}$ & $\begin{array}{l}1.808^{* *} \\
(0.836)\end{array}$ & $\begin{array}{c}-0.286 * * * \\
(0.038)\end{array}$ & $\begin{array}{c}0.724 \\
(1.101)\end{array}$ & $\begin{array}{c}-0.364^{* * *} \\
(0.055)\end{array}$ & $\begin{array}{c}3.524 * * * \\
(1.341)\end{array}$ \\
\hline Male & $\begin{array}{l}1.261^{* *} \\
(0.616)\end{array}$ & $\begin{array}{l}1.947 * * \\
(0.774)\end{array}$ & $\begin{array}{c}0.087 \\
(0.997)\end{array}$ & $\begin{array}{l}1.182^{* *} \\
(0.514)\end{array}$ & $\begin{array}{l}1.669 * * \\
(0.657)\end{array}$ & $\begin{array}{c}0.434 \\
(0.831)\end{array}$ & $\begin{array}{l}0.046^{*} \\
(0.024)\end{array}$ & $\begin{array}{c}0.415 \\
(0.595)\end{array}$ & $\begin{array}{l}0.051^{*} \\
(0.029)\end{array}$ & $\begin{array}{l}1.373^{*} \\
(0.752)\end{array}$ & $\begin{array}{l}0.063 * \\
(0.036)\end{array}$ & $\begin{array}{l}-1.309 \\
(0.962)\end{array}$ \\
\hline Birth order & $\begin{array}{l}-0.482 \\
(0.804)\end{array}$ & $\begin{array}{l}-1.517 \\
(1.016)\end{array}$ & $\begin{array}{c}1.664 \\
(1.344)\end{array}$ & $\begin{array}{l}-0.425 \\
(0.649)\end{array}$ & $\begin{array}{l}-1.414^{*} \\
(0.828)\end{array}$ & $\begin{array}{c}1.563 \\
(1.080)\end{array}$ & $\begin{array}{l}-0.016 \\
(0.033)\end{array}$ & $\begin{array}{l}-0.635 \\
(0.756)\end{array}$ & $\begin{array}{l}-0.044 \\
(0.040)\end{array}$ & $\begin{array}{l}-1.409 \\
(0.959)\end{array}$ & $\begin{array}{c}0.071 \\
(0.050)\end{array}$ & $\begin{array}{c}0.842 \\
(1.256)\end{array}$ \\
\hline \multicolumn{13}{|l|}{ Parental education (maximum) } \\
\hline Not completed primary & $\begin{array}{c}0.371 \\
(1.176)\end{array}$ & $\begin{array}{l}-0.798 \\
(1.562)\end{array}$ & $\begin{array}{c}2.786 \\
(1.870)\end{array}$ & $\begin{array}{c}0.762 \\
(1.040)\end{array}$ & $\begin{array}{c}-0.385 \\
(1.359)\end{array}$ & $\begin{array}{l}3.030^{*} \\
(1.764)\end{array}$ & $\begin{array}{l}-0.002 \\
(0.042)\end{array}$ & $\begin{array}{c}-0.776 \\
(1.269)\end{array}$ & $\begin{array}{l}-0.050 \\
(0.054)\end{array}$ & $\begin{array}{l}-1.372 \\
(1.647)\end{array}$ & $\begin{array}{c}0.067 \\
(0.062)\end{array}$ & $\begin{array}{c}0.598 \\
(2.142)\end{array}$ \\
\hline Completed primary & $\begin{array}{l}2.397 * * \\
(1.158)\end{array}$ & $\begin{array}{c}0.052 \\
(1.378)\end{array}$ & $\begin{array}{c}5.624 * * * \\
(1.899)\end{array}$ & $\begin{array}{c}2.669^{* * *} \\
(0.920)\end{array}$ & $\begin{array}{c}0.651 \\
(1.229)\end{array}$ & $\begin{array}{c}5.637 * * * \\
(1.387)\end{array}$ & $\begin{array}{l}0.085^{* * *} \\
(0.038)\end{array}$ & $\begin{array}{c}0.513 \\
(1.117)\end{array}$ & $\begin{array}{l}0.104 * * \\
(0.052)\end{array}$ & $\begin{array}{l}-2.078 \\
(1.444)\end{array}$ & $\begin{array}{c}0.070 \\
(0.052)\end{array}$ & $\begin{array}{c}5.126^{* * * *} \\
(1.724)\end{array}$ \\
\hline Completed lower secondary & $\begin{array}{l}2.390 * * \\
(1.132)\end{array}$ & $\begin{array}{l}-0.109 \\
(1.425)\end{array}$ & $\begin{array}{c}6.118^{* * *} \\
(1.811)\end{array}$ & $\begin{array}{c}2.459 * * * \\
(0.905)\end{array}$ & $\begin{array}{c}0.154 \\
(1.260)\end{array}$ & $\begin{array}{c}5.946 * * * \\
(1.366)\end{array}$ & $\begin{array}{c}0.079 * * \\
(0.036)\end{array}$ & $\begin{array}{c}0.869 \\
(1.089)\end{array}$ & $\begin{array}{c}0.042 \\
(0.049)\end{array}$ & $\begin{array}{l}-1.109 \\
(1.490)\end{array}$ & $\begin{array}{c}0.132 * * * \\
(0.047)\end{array}$ & $\begin{array}{l}4.041^{* *} \\
(1.639)\end{array}$ \\
\hline $\begin{array}{l}\text { Completed secondary and } \\
\text { above }\end{array}$ & $3.351^{* * *}$ & $2.515^{*}$ & $5.586^{* * *}$ & $3.103^{* * *}$ & $2.256^{* *}$ & $5.415^{* * *}$ & $0.087^{* *}$ & $1.844^{*}$ & 0.075 & 1.421 & $0.136^{* * *}$ & $3.665^{* *}$ \\
\hline & $(1.010)$ & $(1.337)$ & $(1.778)$ & $(0.805)$ & $(1.026)$ & $(1.425)$ & $(0.037)$ & $(0.977)$ & $(0.046)$ & $(1.233)$ & $(0.051)$ & $(1.690)$ \\
\hline Constant & $\begin{array}{c}-41.281 * * * \\
(9.928)\end{array}$ & $\begin{array}{c}-55.061 * * * \\
(13.821)\end{array}$ & $\begin{array}{l}-14.217 \\
(15.912)\end{array}$ & $\begin{array}{c}-39.938^{* * *} \\
(8.246)\end{array}$ & $\begin{array}{c}-51.471^{* * *} \\
(12.159)\end{array}$ & $\begin{array}{l}-20.157 \\
(12.469)\end{array}$ & & $\begin{array}{l}-12.922 \\
(9.745)\end{array}$ & & $\begin{array}{c}-35.128^{* *} \\
(14.142)\end{array}$ & & $\begin{array}{l}24.694 * \\
(14.619)\end{array}$ \\
\hline Observations & 605 & 364 & 241 & 605 & 364 & 241 & 605 & 489 & 364 & 299 & 241 & 190 \\
\hline $\mathrm{R}^{2} /$ Pseudo-R ${ }^{2}$ & 0.25 & 0.30 & 0.29 & 0.05 & 0.06 & 0.06 & & 0.14 & & 0.21 & & 0.26 \\
\hline Log likelihood & & & & -1848 & -1114 & -715.4 & -174.3 & & -103.0 & & -59.37 & \\
\hline
\end{tabular}

Note. See Table 4. Similar to Table 4, caste/ethnicity dummies and development regions dummies are included in the models but estimates are not included for brevity and are available upon request. 


\section{Appendix A.1: Tobit and Hurdle Models}

The OLS estimates on educational investment may suffer from two major limitations. First, the estimates could be a corner solution outcome. Some households did not send their children to school at all, took their children out of school when they had completed a certain level, or made no expenditure on the education of children currently attending school. In those cases, the OLS estimates may be inconsistent (Wooldridge, 2002, p. 524). Second, the OLS estimates may be biased downward when a large proportion of sample households have a corner solution at zero (Deaton, 1997). However, we can consistently estimate the Engel curve using a Tobit model based on the assumption that the same mechanism drives both the "participation decision" (i.e., with zero expenditure on education) and the "amount decision" (i.e., the level of expenditure on education):

$$
\begin{aligned}
& \operatorname{HEDU}_{\mathrm{i}}^{*}=\beta_{0}+\beta \mathrm{HX}_{\mathrm{i}}+\varepsilon_{\mathrm{i}} \\
& \operatorname{HEDU}_{\mathrm{i}}=\operatorname{HEDU}_{\mathrm{i}}^{*} \text { if HEDU} \mathrm{HE}_{\mathrm{i}}^{*}>0 \text { and } \\
& \operatorname{HEDU}_{\mathrm{i}}=0 \text { otherwise }
\end{aligned}
$$

whereHEDU* is a latent variable of the observed counterpart variable HEDU*, and $\varepsilon_{\mathrm{i}}$ is the error term. $\mathrm{HX}_{\mathrm{i}}$ is a set of explanatory variables $\left(\mathrm{M}_{\mathrm{i}}, \mathrm{EXP}_{\mathrm{i}}, \mathrm{H}_{\mathrm{i}}, \mathrm{C}_{\mathrm{i}}\right.$, and $\left.\mathrm{D}_{\mathrm{i}}\right)$, which are the same as in Model (4). Following Wooldridge's approach (2002, p. 522-523), the conditional marginal effect of an explanatory variable, for instance $\mathrm{HX}_{\mathrm{j}}$, is as follows:

$$
\frac{\partial \mathrm{E}(\mathrm{HEDU} \mid \mathrm{HX}, \mathrm{HEDU}>0)}{\partial \mathrm{HX}_{\mathrm{j}}}=\beta_{\mathrm{j}}\{(1-\lambda(\mathrm{c})[\mathrm{c}+\lambda(\mathrm{c})]\}
$$

where $\lambda(\mathrm{c})=\phi(\mathrm{c}) / \Phi(\mathrm{c})$ is the inverse Mills ratio, $\mathrm{c}=\mathrm{HX} \beta / \sigma_{\mathrm{h}}, \phi($.$) and \Phi($.$) are the probability$ and cumulative density functions, respectively, and $\sigma_{\mathrm{h}}$ is the standard deviation of the error term $\varepsilon_{\mathrm{hi}}$.

The Tobit model is too restrictive because it assumes that the same mechanism determines both the "participation decision" and the "amount decision." In other words, it assumes that the effect of an explanatory variable on both the probability of positive expenditure and the amount of expenditure has the same sign. However, zero outcomes may occur owing to a lack of preference concerning education, while variation in the amount of positive expenditure may occur due to budget constraints. Therefore, we also use a hurdle model (Cameron \& Trivedi, 2005; Wooldridge, 2002), which allows participation in education expenditure and the amount of education expenditure to be determined by different 
processes or sets of variables. If the participation condition in equation (4A4) is satisfied, then the amount of education expenditure is determined by equation (4A5):

$$
\begin{aligned}
& \text { HAVEHEDU }_{\mathrm{i}}^{*}=\beta_{0}+\beta \mathrm{HZ}_{\mathrm{i}}+\mathrm{u}_{\mathrm{i}} \\
& \text {HEDU }_{\mathrm{i}}=1\left[\text { HAVEHEDU }_{\mathrm{i}}^{*}>0\right]\left(\beta_{0}+\Gamma \mathrm{HS}_{\mathrm{i}}+\mathrm{v}_{\mathrm{i}}\right)
\end{aligned}
$$

where equation (4A4) is a probit model with latent dependent variable HAVEHEDU*. Equation (4A5) is estimated via linear regression truncated at zero (i.e., it is estimated using households that made expenditures on education). The dependent variable HEDU in equation (4A5) is the natural logarithm of education expenditure. The explanatory variables $\mathrm{HZ}$ and HS are specified in the same way as HX in Model (4A2), but their coefficients in equations (4A4) and (4A5) are allowed to enter with different coefficients. $\beta$ and $\Gamma$ are the vectors of the parameters to be estimated. The error terms $u_{i}$ and $v_{i}$ are independent of each other, as well as of HZ and HS.

\section{Appendix A.2. Household Survey Data and Construction of Variables}

We collected household data through individual interviews using a pilot-tested household questionnaire. The questionnaire asked about household demographics, income, expenditures, education, land, housing, durable goods and other real asset holdings, and entrepreneurship. Specifically, it captured detailed information about in-migration and out-migration (from the household's hometown to other parts of Nepal and abroad). Data were collected at both the individual and household levels, depending on the nature of the information required. We complemented this questionnaire with a community questionnaire administered at the PSU level to capture information about the prices of major commodities, access to major facilities and services, such as schools, transportation, communication, health, banking, and financial services, and the overall pattern of in-migration and out-migration. The construction of income and consumption expenditure and the definitions of the variables used in the models are presented in Table A.1. 
Table A.1Construction and Definition of Key Variables

Variable Definition

A. Income and Expenditure

Household Income

Wage or salary income, farm income, enterprise income, non-agriculture assets rental income or owner occupied housing, pension income, domestic remittance income and international remittance and income from sale of assets such as land, house, etc.

Wage income

Value of cash or in-kind earnings from daily, piece-rate and permanent employment

Farm income

Value of crop and non-crop production that is consumed by the household or sold out and cash or in-kind received from tenants on farm share cropped-out or leased-out minus costs on cultivation (seeds, fertilizers, hired labor, irrigation), fodder and other livestock expenses and cash or in-kind paid to the landlord

Enterprise income

Gross revenue from enterprise activities minus expenses on wages, raw material, fuel, rent and other operating expenses during past 12 months

Non-agriculture assets rental Earnings from renting out houses, no-agricultural land, and other real assets income or owner occupied and imputed or reported value of housing that would have to paid to purchase housing services

housing

Social security benefits provided by the previous employers or universal pension provided by the government

Domestic remittance

International remittance

Monies or goods sent by the absent members of the households who are staying in other parts of the country during past 12 months

Monies or goods sent by the absent members of the households who are staying abroad during past 12 months(excluding remittance received from friends and relatives)

Household consumption expenditure

Expenditure on food, non-food, durables consumption and expenditure on education (excluding expenses on health, festivals, marriage and dowry as well as expenses on purchase of land, housing, durable assets, jewelry and productive investments).

Food

Non-food

Expenses on foods purchased and the values of consumption of ownproduced foods within past seven days and annualized.

Monies spent on clothes and footwear, tobacco, house rent or user value of housing, utilities such as gas, electricity, water and fuel and transport within past 12 months.

Education

Monies spent on currently school going children aged 5 through 24 including tuition fees, admission, exam and other fees, text books and stationary, uniforms, transport, private and other expenditure related to schooling within past 12 months.

Durables services

Value of the services flow from the durable holdings purchased at least 12 months prior to the survey year which is computed based on the reported value of the durables during the time of purchase and it current value as well as inflation rate in the country.

Household income divided by household size

Per capita household income

Household consumption expenditure divided by household size 


\begin{tabular}{|c|c|}
\hline Variable & Definition \\
\hline \multicolumn{2}{|l|}{ expenditure } \\
\hline \multicolumn{2}{|l|}{ B. Explanatory variables } \\
\hline \multicolumn{2}{|l|}{ Migration } \\
\hline Urban-native household (L) & $\begin{array}{l}1 \text { if a households has been living in the PSU for a very long time or arrived } \\
\text { other local administrative units i.e. village development committee (VDC) or } \\
\text { municipality before or within } 2001\end{array}$ \\
\hline Migrant household (M) & 1 if a household arrived in the PSU after 2001 \\
\hline Years since migration (YSM) & Completed years after arrival in the PSU \\
\hline $\begin{array}{l}\text { Post Conflict migrant household } \\
\text { (M0TO5) }\end{array}$ & 1 if a household arrived in the PSU after conflict (2007-) \\
\hline $\begin{array}{l}\text { Inter-conflict migrant household } \\
\text { (M6TO15) }\end{array}$ & 1 if a household arrived in the PSU during civil conflict (1996-2006) \\
\hline $\begin{array}{l}\text { Prior-conflict migrant household } \\
\text { (M16TO20) }\end{array}$ & 1 if a household arrived in the PSU before civil conflict (1991-1995) \\
\hline Household size & Number of people in the household including absent members \\
\hline Absent members of the household & $\begin{array}{l}\text { Individuals who lived in their home town less than six months during past } 12 \\
\text { months }\end{array}$ \\
\hline $\begin{array}{l}\text { Maximum years of schooling of } \\
\text { household members }\end{array}$ & $\begin{array}{l}\text { Years of schooling completed by the most educated member of the } \\
\text { households among aged } 25 \text { and above }\end{array}$ \\
\hline Birth order & $\begin{array}{l}\text { The order of the child among the siblings multiplied by two and divided by } \\
\text { one plus total number of siblings }\end{array}$ \\
\hline \multicolumn{2}{|l|}{$\begin{array}{l}\text { Maximum educational level of } \\
\text { parents }\end{array}$} \\
\hline Illiterate & $\begin{array}{l}\text { Both parents having no formal schooling or cannot read or write (base } \\
\text { category) }\end{array}$ \\
\hline Literate but no formal schooling & No formal schooling but at least one of them can read and write \\
\hline Primary & At least one of them having five years of schooling \\
\hline Lower secondary & At least one of them having six to eight years of schooling \\
\hline Secondary & At least one of them having eight to 10 years of schooling \\
\hline Tertiary & At least one of them having more than 10 years of schooling \\
\hline
\end{tabular}


Table A.2OLS and Tobit Estimates of Natural Logarithm of Household Expenditure on Education (Household Level)

\begin{tabular}{|c|c|c|c|c|c|c|}
\hline \multirow{4}{*}{ Variables } & \multicolumn{3}{|c|}{ A. OLS Model } & \multicolumn{3}{|c|}{ B. Tobit Model } \\
\hline & All & $\begin{array}{l}\text { No member } \\
\text { abroad }\end{array}$ & $\begin{array}{l}\text { Member } \\
\text { abroad }\end{array}$ & All & $\begin{array}{l}\text { No member } \\
\text { abroad }\end{array}$ & $\begin{array}{l}\text { Member } \\
\text { abroad }\end{array}$ \\
\hline & Coeff. & Coeff. & Coeff. & $\begin{array}{l}\text { Condi. } \\
\text { Mar. Effect }\end{array}$ & $\begin{array}{l}\text { Condi. Mar. } \\
\text { Effect }\end{array}$ & $\begin{array}{l}\text { Condi. Mar. } \\
\text { Effect }\end{array}$ \\
\hline & (1) & (2) & (3) & (4) & (5) & (6) \\
\hline \multirow[t]{2}{*}{ Migrant household (M) } & $0.873^{* *}$ & 0.281 & $0.921 * *$ & $0.958 * *$ & 0.324 & $0.981 *$ \\
\hline & $(0.340)$ & $(0.709)$ & $(0.457)$ & $(0.396)$ & $(0.596)$ & $(0.517)$ \\
\hline \multirow[t]{2}{*}{ Log of household expenditure } & $2.047 * * *$ & $2.273 * *$ & $1.973 * * *$ & $2.173 * * *$ & $2.329 * * *$ & $2.109 * * *$ \\
\hline & $(0.465)$ & $(1.032)$ & $(0.564)$ & $(0.463)$ & $(0.750)$ & $(0.604)$ \\
\hline \multirow[t]{2}{*}{$\begin{array}{l}\text { Years of schooling of the most educated } \\
\text { adult aged } 25\end{array}$} & $0.117 * * *$ & 0.070 & $0.147 * *$ & $0.130 * * *$ & 0.081 & $0.164 * *$ \\
\hline & $(0.043)$ & $(0.085)$ & $(0.057)$ & $(0.046)$ & $(0.066)$ & $(0.066)$ \\
\hline \multirow[t]{2}{*}{ Log of household size } & 0.493 & -0.400 & 0.650 & 0.572 & -0.441 & 0.738 \\
\hline & $(0.483)$ & $(1.183)$ & $(0.570)$ & $(0.501)$ & $(0.986)$ & $(0.655)$ \\
\hline \multirow[t]{2}{*}{ Proportion of children aged $0-4$} & -4.483 & -6.119 & -1.083 & $-5.235 * *$ & $-7.464 * *$ & -1.428 \\
\hline & $(2.838)$ & $(5.105)$ & $(3.260)$ & $(2.648)$ & $(3.619)$ & $(3.740)$ \\
\hline \multirow[t]{2}{*}{ Proportion of children aged 5-10 } & $8.188 * * *$ & 6.437 & $10.017 * * *$ & $8.859 * * *$ & $6.710^{*}$ & $10.979 * * *$ \\
\hline & $(2.665)$ & $(4.812)$ & $(2.881)$ & $(2.596)$ & $(3.671)$ & $(3.409)$ \\
\hline \multirow[t]{2}{*}{ Proportion of children aged 11-16 } & 3.867 & 3.910 & 4.314 & $4.100 *$ & 3.795 & 4.704 \\
\hline & $(2.616)$ & $(4.683)$ & $(2.936)$ & $(2.408)$ & $(3.327)$ & $(3.187)$ \\
\hline \multirow[t]{2}{*}{ Proportion of children aged $17-24$} & 3.070 & 3.372 & 2.735 & 3.276 & 3.167 & 3.060 \\
\hline & $(2.405)$ & $(4.144)$ & $(2.629)$ & $(2.452)$ & $(3.643)$ & $(3.162)$ \\
\hline \multirow[t]{2}{*}{ Proportion of working age men (25-64) } & 0.470 & 4.300 & -1.391 & 0.611 & 4.537 & -1.405 \\
\hline & $(2.874)$ & $(5.005)$ & $(3.991)$ & $(2.692)$ & $(4.110)$ & $(3.559)$ \\
\hline \multirow[t]{2}{*}{ Proportion of working age women (25-64) } & 3.826 & 4.703 & 2.498 & 4.225 & 4.788 & 2.708 \\
\hline & $(2.440)$ & $(4.242)$ & $(3.131)$ & $(2.849)$ & $(4.007)$ & $(3.906)$ \\
\hline \multicolumn{7}{|l|}{ Caste/Ethnicity } \\
\hline \multirow[t]{2}{*}{ Brahmin-Hills } & 0.447 & -0.517 & 0.953 & 0.528 & -0.504 & 1.106 \\
\hline & $(0.567)$ & $(0.847)$ & $(0.737)$ & $(0.636)$ & $(0.948)$ & $(0.824)$ \\
\hline \multirow[t]{2}{*}{ Brahmin-Tarai } & 0.133 & -1.153 & $1.692 * *$ & 0.147 & -1.348 & 1.861 \\
\hline & $(0.622)$ & $(1.138)$ & $(0.796)$ & $(0.923)$ & $(1.258)$ & $(1.323)$ \\
\hline \multirow[t]{2}{*}{ Chhetri } & 0.272 & -0.611 & 0.477 & 0.314 & -0.615 & 0.556 \\
\hline & $(0.489)$ & $(0.789)$ & $(0.656)$ & $(0.596)$ & $(0.934)$ & $(0.746)$ \\
\hline \multirow[t]{2}{*}{ Newar } & 0.018 & 0.608 & 0.099 & 0.062 & 0.711 & 0.166 \\
\hline & $(1.007)$ & $(0.857)$ & $(1.348)$ & $(0.977)$ & $(1.547)$ & $(1.238)$ \\
\hline \multirow[t]{2}{*}{ Ethnic Groups -Hills } & -0.979 & $-2.860 * *$ & -0.146 & -1.082 & $-3.301 * * *$ & -0.103 \\
\hline & $(0.629)$ & $(1.308)$ & $(0.780)$ & $(0.691)$ & $(1.112)$ & $(0.850)$ \\
\hline \multirow[t]{2}{*}{ Dalit } & $1.525 * *$ & 0.445 & $2.033 * *$ & $1.757 * *$ & 0.557 & $2.344 * *$ \\
\hline & $(0.726)$ & $(1.001)$ & $(1.009)$ & $(0.767)$ & $(1.099)$ & $(0.989)$ \\
\hline \multirow[t]{2}{*}{ Constant } & $-21.328 * * *$ & $-21.814^{*}$ & $-21.19 * * *$ & $-23.476^{* * *}$ & $-22.495 * *$ & $-23.646 * * *$ \\
\hline & $(5.940)$ & $(12.935)$ & $(6.371)$ & $(5.812)$ & $(9.249)$ & (7.443) \\
\hline \multirow{4}{*}{$\begin{array}{l}\text { Observations } \\
\text { Left censored observations } \\
\mathrm{R}^{2} / \text { Pseudo- } \mathrm{R}^{2} \\
\text { Log likelihood }\end{array}$} & 247 & 93 & 154 & 247 & 93 & 154 \\
\hline & & & & 22 & 8 & 14 \\
\hline & 0.419 & 0.555 & 0.425 & 0.108 & 0.165 & 0.109 \\
\hline & & & & -551.2 & -192.9 & -344.6 \\
\hline
\end{tabular}


Table A.3Multinomial logit estimation for determinants of school choice among children aged 5-24

\begin{tabular}{|c|c|c|c|c|c|c|}
\hline \multirow[b]{2}{*}{ Variables } & \multicolumn{2}{|c|}{ All } & \multicolumn{2}{|c|}{ Remittance non-recipient } & \multicolumn{2}{|c|}{ Remittance recipient } \\
\hline & $\begin{array}{l}\text { Public } \\
\text { School }\end{array}$ & Private school & Public School & Private school & $\begin{array}{l}\text { Public } \\
\text { School }\end{array}$ & $\begin{array}{r}\text { Private } \\
\text { school }\end{array}$ \\
\hline \multirow[t]{2}{*}{ Migrant household (M) } & $0.757 *$ & 0.597 & 0.568 & -0.112 & $1.752 * *$ & $1.832 * *$ \\
\hline & $(0.393)$ & $(0.439)$ & $(0.573)$ & $(0.611)$ & $(0.740)$ & $(0.871)$ \\
\hline \multirow{2}{*}{$\begin{array}{l}\text { Log of household } \\
\text { expenditure }\end{array}$} & $1.809 * * *$ & $3.495 * * *$ & $2.022 * * *$ & $4.216^{* * *}$ & $1.493^{*}$ & $3.374 * * *$ \\
\hline & $(0.445)$ & $(0.537)$ & $(0.706)$ & $(0.825)$ & $(0.836)$ & $(1.019)$ \\
\hline \multirow[t]{2}{*}{ Log of household size } & $-1.168 * * *$ & $-2.285 * * *$ & $-1.115^{*}$ & $-2.873 * * *$ & -1.039 & $-2.479 * *$ \\
\hline & $(0.448)$ & $(0.548)$ & $(0.653)$ & $(0.830)$ & $(0.868)$ & $(1.093)$ \\
\hline \multicolumn{7}{|l|}{ Child characteristics } \\
\hline \multirow{2}{*}{$\begin{array}{l}\text { Secondary school age } \\
\text { cohort }\end{array}$} & -0.871 & $-2.688 * * *$ & 0.086 & -1.393 & $-2.167 *$ & $-4.491 * * *$ \\
\hline & $(0.715)$ & $(0.750)$ & $(0.989)$ & $(1.038)$ & $(1.259)$ & $(1.355)$ \\
\hline \multirow[t]{2}{*}{ Tertiary school age cohort } & $-3.776 * * *$ & $-6.640 * * *$ & $-3.587 * * *$ & $-5.950 * * *$ & $-4.291 * * *$ & $-8.928 * * *$ \\
\hline & $(0.697)$ & $(0.765)$ & $(0.881)$ & $(0.976)$ & $(1.329)$ & $(1.536)$ \\
\hline \multirow[t]{2}{*}{ Male } & 0.447 & $1.146^{* * *}$ & 0.456 & $1.640 * * *$ & $1.137^{*}$ & 0.820 \\
\hline & $(0.302)$ & $(0.359)$ & $(0.417)$ & $(0.499)$ & $(0.593)$ & $(0.699)$ \\
\hline \multirow[t]{2}{*}{ Birth order } & 0.182 & $-0.809^{*}$ & -0.247 & $-1.254 * *$ & $1.455^{*}$ & 0.549 \\
\hline & $(0.373)$ & $(0.448)$ & $(0.498)$ & $(0.601)$ & $(0.766)$ & $(0.902)$ \\
\hline \multicolumn{7}{|l|}{$\begin{array}{l}\text { Maximum education level } \\
\text { of parents }\end{array}$} \\
\hline \multirow[t]{2}{*}{ Not completed primary } & 0.341 & 0.247 & -0.508 & -0.419 & 1.006 & 1.557 \\
\hline & $(0.505)$ & $(0.726)$ & $(0.772)$ & (1.039) & $(1.012)$ & $(1.395)$ \\
\hline \multirow[t]{2}{*}{ Completed primary } & 0.620 & $2.100 * * *$ & 0.876 & $1.871 * *$ & 0.485 & $3.522 * * *$ \\
\hline & $(0.463)$ & $(0.625)$ & $(0.709)$ & $(0.876)$ & $(0.794)$ & $(1.141)$ \\
\hline \multirow{2}{*}{$\begin{array}{l}\text { Completed lower } \\
\text { secondary }\end{array}$} & 0.233 & $2.288 * * *$ & -0.302 & $1.708 * *$ & 1.242 & $3.649 * * *$ \\
\hline & $(0.484)$ & $(0.611)$ & $(0.675)$ & $(0.829)$ & $(0.875)$ & $(1.120)$ \\
\hline \multirow{2}{*}{$\begin{array}{l}\text { Completed secondary and } \\
\text { above }\end{array}$} & 0.602 & $2.643 * * *$ & 0.428 & $2.452 * * *$ & 0.877 & $4.468 * * *$ \\
\hline & $(0.430)$ & $(0.579)$ & $(0.547)$ & $(0.754)$ & $(0.949)$ & $(1.178)$ \\
\hline \multicolumn{7}{|l|}{ Caste/Ethnicity } \\
\hline \multirow[t]{2}{*}{ Brahmin-Hills } & 0.223 & 0.320 & 0.204 & 0.218 & -0.104 & 0.369 \\
\hline & $(0.604)$ & $(0.705)$ & $(0.999)$ & $(1.129)$ & $(1.188)$ & $(1.310)$ \\
\hline Brahmin-Tarai & 0.051 & 1.312 & -0.849 & 0.916 & 14.368 & 14.199 \\
\hline & $(1.406)$ & $(1.400)$ & $(1.699)$ & $(1.663)$ & $(1,897.160)$ & $(1,897.16)$ \\
\hline Chhetri & $-0.965^{*}$ & -0.422 & -1.297 & -0.746 & -0.801 & -1.153 \\
\hline & $(0.559)$ & $(0.641)$ & $(1.010)$ & $(1.103)$ & $(0.880)$ & $(1.084)$ \\
\hline Newar & -0.602 & -0.605 & -2.321 & -1.789 & 0.657 & -2.324 \\
\hline & $(0.894)$ & (1.072) & (1.641) & $(1.683)$ & (1.401) & $(2.250)$ \\
\hline Ethnic-Hills & -0.658 & -0.582 & -0.953 & 0.498 & 0.029 & -1.984 \\
\hline & $(0.665)$ & $(0.762)$ & $(1.155)$ & $(1.304)$ & $(1.054)$ & $(1.261)$ \\
\hline Dalit & -0.671 & $-1.480 *$ & -0.768 & -1.388 & 1.223 & -1.711 \\
\hline & $(0.684)$ & $(0.858)$ & (1.094) & $(1.332)$ & (1.193) & $(1.494)$ \\
\hline Development regions & & & & & & \\
\hline Eastern & $-1.063 *$ & 1.028 & -0.945 & $1.578^{*}$ & 0.508 & -0.158 \\
\hline & $(0.631)$ & $(0.742)$ & $(0.839)$ & $(0.949)$ & $(1.336)$ & $(1.696)$ \\
\hline Central & $-1.377 * *$ & $1.568 * *$ & $-2.066 * * *$ & $1.406^{*}$ & 0.726 & 1.358 \\
\hline & $(0.565)$ & $(0.674)$ & $(0.751)$ & $(0.854)$ & $(1.146)$ & $(1.492)$ \\
\hline Western & $-2.239 * * *$ & -0.083 & -1.379 & 0.657 & $-2.076^{*}$ & -1.563 \\
\hline & $(0.595)$ & $(0.699)$ & $(0.879)$ & $(0.999)$ & (1.118) & (1.411) \\
\hline Mid-western & $-1.659 * * *$ & 0.418 & $-1.883 * * *$ & -0.176 & -0.473 & 0.316 \\
\hline & $(0.510)$ & $(0.636)$ & $(0.670)$ & (0.849) & $(1.085)$ & $(1.411)$ \\
\hline Constant & $-15.865 * * *$ & $-36.080 * * *$ & $-17.840^{* *}$ & $-43.978 * * *$ & $-15.481 *$ & $-34.062 * * *$ \\
\hline & (4.853) & (5.962) & $(8.147)$ & $(9.560)$ & (8.679) & $(10.782)$ \\
\hline Observations & 602 & 602 & 361 & 361 & 241 & 241 \\
\hline Pseudo R2 & 0.415 & 0.415 & 0.433 & 0.433 & 0.544 & 0.544 \\
\hline Log likelihood & -366.9 & -366.9 & -210.8 & -210.8 & -113.6 & -113.6 \\
\hline
\end{tabular}


Table A.4OLS, Tobit and Two-Part Estimates of Expenditure on Education

(Consideration of alternative definition of migrant households, conflict-induced migration and temoral variation in investment in education)

\begin{tabular}{|c|c|c|c|c|c|c|}
\hline \multirow{4}{*}{ Variables } & \multicolumn{3}{|c|}{ OLS Model } & \multicolumn{3}{|c|}{ Tobit Model } \\
\hline & All & $\begin{array}{c}\text { Remittance } \\
\text { non-recipient }\end{array}$ & $\begin{array}{c}\text { Remittance } \\
\text { recipient }\end{array}$ & All & $\begin{array}{c}\text { Remittance } \\
\text { non-recipient }\end{array}$ & $\begin{array}{c}\text { Remittance } \\
\text { recipient }\end{array}$ \\
\hline & Coeff. & Coeff. & Coeff. & $\begin{array}{l}\text { Condi. } \\
\text { Mar. } \\
\text { Effect }\end{array}$ & $\begin{array}{l}\text { Condi. Mar. } \\
\text { Effect }\end{array}$ & $\begin{array}{c}\text { Condi. Mar. } \\
\text { Effect }\end{array}$ \\
\hline & (1) & (2) & (3) & (4) & (5) & (6) \\
\hline \multicolumn{7}{|c|}{ A. Dependent Variable: Natural logarithm of expenditure on education (Household level) } \\
\hline Prior-conflict migrant household (M16TO20) & $\begin{array}{l}-1.474 \\
(1.187)\end{array}$ & $\begin{array}{l}-1.371 \\
(1.555)\end{array}$ & $\begin{array}{l}-1.999 \\
(1.333)\end{array}$ & $\begin{array}{l}-1.625^{*} \\
(0.880)\end{array}$ & $\begin{array}{l}-1.432 \\
(0.906)\end{array}$ & $\begin{array}{l}-2.532 \\
(1.989)\end{array}$ \\
\hline Inter-conflict migrant household (M6TO15) & $\begin{array}{c}0.557 \\
(0.366)\end{array}$ & $\begin{array}{c}0.231 \\
(0.478)\end{array}$ & $\begin{array}{l}1.810 * * \\
(0.690)\end{array}$ & $\begin{array}{c}0.597 \\
(0.444)\end{array}$ & $\begin{array}{c}0.255 \\
(0.562)\end{array}$ & $\begin{array}{c}1.966 * * * \\
(0.714)\end{array}$ \\
\hline Post-conflict migrant household (M0TO5) & $\begin{array}{c}0.692 \\
(0.438)\end{array}$ & $\begin{array}{c}0.144 \\
(0.572)\end{array}$ & $\begin{array}{l}1.423^{*} \\
(0.814)\end{array}$ & $\begin{array}{l}0.760 * \\
(0.459)\end{array}$ & $\begin{array}{c}0.156 \\
(0.550)\end{array}$ & $\begin{array}{l}1.572 * * \\
(0.714)\end{array}$ \\
\hline Observations & 247 & 145 & 102 & 247 & 145 & 102 \\
\hline \multicolumn{7}{|c|}{ B. Dependent Variable: Budget share (\%) of expenditure on education (Household level) } \\
\hline Prior-conflict migrant household (M16TO20) & $\begin{array}{c}0.348 \\
(3.218)\end{array}$ & $\begin{array}{c}0.791 \\
(3.992)\end{array}$ & $\begin{array}{l}-1.930 \\
(2.646)\end{array}$ & $\begin{array}{l}-0.107 \\
(1.805)\end{array}$ & $\begin{array}{c}0.395 \\
(2.065)\end{array}$ & $\begin{array}{l}-2.387 \\
(4.138)\end{array}$ \\
\hline Inter-conflict migrant household (M6TO15) & $\begin{array}{c}1.209 \\
(1.091)\end{array}$ & $\begin{array}{c}1.280 \\
(1.775)\end{array}$ & $\begin{array}{c}2.594 \\
(1.905)\end{array}$ & $\begin{array}{c}1.184 \\
(0.903)\end{array}$ & $\begin{array}{c}1.150 \\
(1.276)\end{array}$ & $\begin{array}{c}2.973 * * \\
(1.431)\end{array}$ \\
\hline Post-conflict migrant household (M0TO5) & $\begin{array}{c}2.315 * * \\
(1.135)\end{array}$ & $\begin{array}{c}0.290 \\
(1.495)\end{array}$ & $\begin{array}{l}4.090 * * \\
(2.008)\end{array}$ & $\begin{array}{c}2.195 * * \\
(0.939)\end{array}$ & $\begin{array}{c}0.361 \\
(1.258)\end{array}$ & $\begin{array}{c}4.260 * * * \\
(1.427)\end{array}$ \\
\hline Observations & 247 & 145 & 102 & 247 & 145 & 102 \\
\hline \multicolumn{7}{|c|}{ C. Dependent Variable: Natural logarithm of expenditure on education (children age 5-24) } \\
\hline Prior-conflict migrant household (M16TO20) & $\begin{array}{c}0.145 \\
(0.822)\end{array}$ & $\begin{array}{c}0.148 \\
(1.027)\end{array}$ & $\begin{array}{l}-1.053 \\
(1.807)\end{array}$ & $\begin{array}{c}0.176 \\
(0.770)\end{array}$ & $\begin{array}{c}0.174 \\
(0.916)\end{array}$ & $\begin{array}{l}-1.075 \\
(1.670)\end{array}$ \\
\hline Inter-conflict migrant household (M6TO15) & $\begin{array}{c}0.948 * * * \\
(0.334)\end{array}$ & $\begin{array}{c}1.136 * * * \\
(0.421)\end{array}$ & $\begin{array}{l}1.142 * * \\
(0.578)\end{array}$ & $\begin{array}{c}1.026 * * * \\
(0.375)\end{array}$ & $\begin{array}{l}1.276 * * \\
(0.517)\end{array}$ & $\begin{array}{l}1.190 * \\
(0.624)\end{array}$ \\
\hline Post-conflict migrant household (M0TO5) & $\begin{array}{c}0.715^{* *} \\
(0.354)\end{array}$ & $\begin{array}{c}0.166 \\
(0.507)\end{array}$ & $\begin{array}{l}1.207 * * \\
(0.570)\end{array}$ & $\begin{array}{c}0.812 * * \\
(0.389)\end{array}$ & $\begin{array}{c}0.212 \\
(0.545)\end{array}$ & $\begin{array}{l}1.426 * * \\
(0.602)\end{array}$ \\
\hline Observations & 605 & 364 & 241 & 605 & 364 & 241 \\
\hline
\end{tabular}

Note. The control variables are similar to Table 4, 5 and 6 for results reported in the Panel A, B and C respectively and are not reported for convenience. Standard errors in parentheses are robust to heteroskedasticityin Panel A and B whereas these are robust to heteroskedasticity and clustered at residuals within each household in Panel C. *,**, and *** indicate the $10 \%, 5 \%$ and $1 \%$ level of statistical significance respectively. 
Table A.5OLS and Tobit Estimates of Natural Logarithm of Household Expenditure on Education (Household level)

\begin{tabular}{|c|c|c|c|c|c|c|}
\hline \multirow{3}{*}{ Variables } & \multicolumn{3}{|c|}{ OLS } & \multicolumn{3}{|c|}{ Tobit } \\
\hline & All & $\begin{array}{l}\text { Having } \\
\text { member } \\
\text { abroad }\end{array}$ & $\begin{array}{l}\text { Remittance- } \\
\text { recipient }\end{array}$ & All & $\begin{array}{l}\text { Having } \\
\text { member } \\
\text { abroad }\end{array}$ & $\begin{array}{l}\text { Remittance- } \\
\text { recipient }\end{array}$ \\
\hline & (1) & & (2) & (3) & & (4) \\
\hline \multirow{2}{*}{$\begin{array}{l}\text { Migrant household } \\
\text { (migrated after sending member abroad) }\end{array}$} & $1.041 * * *$ & $0.987 * *$ & $1.293 *$ & $1.106^{* *}$ & $1.041^{*}$ & $1.406^{*}$ \\
\hline & $(0.354)$ & $(0.447)$ & $(0.691)$ & $(0.539)$ & $(0.617)$ & $(0.746)$ \\
\hline \multirow{2}{*}{$\begin{array}{l}\text { Migrant household } \\
\text { (migrated before sending member abroad) }\end{array}$} & 0.163 & 0.048 & $1.499 * *$ & 0.185 & 0.054 & $1.680 * *$ \\
\hline & $(0.525)$ & $(0.605)$ & $(0.729)$ & $(0.473)$ & $(0.538)$ & $(0.704)$ \\
\hline \multirow{2}{*}{$\begin{array}{l}\text { Migrant household } \\
\text { (having no member abroad) }\end{array}$} & 0.295 & & & 0.329 & & \\
\hline & $(0.449)$ & & & $(0.504)$ & & \\
\hline Observations & 247 & 154 & 102 & 247 & 154 & 102 \\
\hline R-squared & 0.416 & 0.416 & 0.588 & & & \\
\hline
\end{tabular}

Note.A household is considered as migrant household if arrived in urban area after 1990 and urban-native otherwise. The results are qualitatively similar and robust to the usual definition of migrant household used in the paper. Control variables, similar Table 4 are included but are not reported. Standard errors in parentheses are robust to heteroskedasticity. *, **, and *** indicate the $10 \%, 5 \%$ and $1 \%$ level of statistical significance respectively. 